VALDIR PAVANELO JUNIOR

Expressão do sistema VEGF-A no útero bovino após o tratamento com diferentes doses de eCG 


\section{Expressão do sistema VEGF-A no útero bovino após o tratamento com diferentes doses de eCG}

Dissertação apresentada ao Programa de PósGraduação em Anatomia dos Animais Domésticos e Silvestres da Faculdade de Medicina Veterinária e Zootecnia da Universidade de São Paulo para obtenção do título de Mestre em Ciências.

Departamento:

Cirurgia

Área de Concentração:

Anatomia dos Animais Domésticos e Silvestres

Orientadora:

Profa. Dra. Paula de Carvalho Papa

São Paulo 
Autorizo a reprodução parcial ou total desta obra, para fins acadêmicos, desde que citada a fonte.

DADOS INTERNACIONAIS DE CATALOGAÇÃO-NA-PUBLICAÇÃO

(Biblioteca Virginie Buff D’Ápice da Faculdade de Medicina Veterinária e Zootecnia da Universidade de São Paulo)

Pavanelo Junior, Valdir

Expressão do sistema VEGF-A no útero bovino após o tratamento com diferentes doses de eCG / Valdir Pavanelo Junior. -- 2012.

$76 \mathrm{f}$.

Dissertação (Mestrado) - Universidade de São Paulo. Faculdade de Medicina Veterinária e Zootecnia. Departamento de Cirurgia, São Paulo, 2012.

Programa de Pós-Graduação: Anatomia dos Animais Domésticos e Silvestres.

Área de concentração: Anatomia dos Animais Domésticos e Silvestres.

Orientador: Profa. Dra. Paula de Carvalho Papa.

1. Útero. 2. VEGF-A. 3. ECG. 4. Glândulas uterinas. I. Título. 
PAVANELO JUNIOR, V. Expressão do sistema VEGF-A no útero bovino após o tratamento com diferentes doses de eCG. 2012. f76. Dissertação (Mestrado em Ciências) - Faculdade de Medicina Veterinária e Zootecnia, Universidade de São Paulo, São Paulo, 2012
Página
Parágrafo
Resumo
Onde se lê
Leia-se
Abstract
10
f76.
f76. 
UNIVERSIDADE DE SÃO PAULO

\section{Comissão de Ética no uso de animais}

\section{CERTIFICADO}

Certificamos que o Projeto intitulado "Expressão do sistema VEGF-A no útero bovino após o tratamento com diferentes doses de $\mathrm{eCG}^{\prime \prime}$, protocolado sob o $\mathrm{n}^{\circ}$ 2144/2011, sob a responsabilidade da Profa. Dra. Paula de Carvalho Papa, está de acordo com os princípios éticos de experimentação animal da "Comissão de Ética no uso de animais" da Faculdade de Medicina Veterinária e Zootecnia da Universidade de São Paulo e foi aprovado em reunião de 16/03/2011. As amostras biológicas de bovinos que serão utilizadas neste experimento estão coletadas e processadas, mas ainda não finalizados. São as mesmas amostras utilizadas nos projetos de pesquisa protocolados sob os n's 1637 e 1638/2009, aprovados pela referida Comissão, em 23/4/2009.

We certify that the Research "Expression of VEGF-A system in bovine uterus after treatment with different doses of eCG", protocol number 2144/2011, under the responsibility Profa. Dra. Paula de Carvalho Papa, agree with Ethical Principles in Animal Research adopted by "Ethic Committee in the use of animals" of the School of Veterinary Medicine and Animal Science of University of São Paulo and was approved in the meeting of day 03/16/2011.

São Paulo, 18 de março de 2011

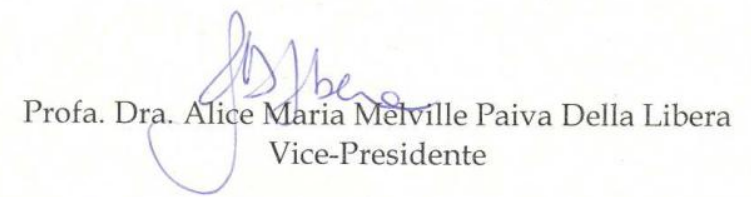

Av. Prof. Dr. Orlando Marques de Paiva, n 87

Cidade Universitária "Armando de Salles Oliveira"

São Paulo/SP - Brasil

05508-270
Fax: +5511 3032-2224/3091-7757 Fone: + $55113091-7671 / 7676$ E-mail: fmvz@usp.br http://www.fmvz.usp.br 
Nome: Pavanelo Junior, Valdir

Título: Expressão do sistema VEGF-A no útero bovino após o tratamento com diferentes doses de eCG

Dissertação apresentada ao Programa de PósGraduação em Anatomia dos Animais Domésticos e Silvestres da Faculdade de Medicina Veterinária e Zootecnia da Universidade de São Paulo para obtenção do título de Mestre em Ciências

Data:

\section{Banca Examinadora}

Prof. Dr,

Instituição:

Prof. Dr,

Instituição:

Prof. Dr,

Instituição: 
No esforço para compreender a realidade, somos como um homem tentando entender o mecanismo de um relógio fechado. Ele vê o mostrador e os ponteiros, ouve o seu tique-taque, mas não tem meios para abrir a caixa. Se esse homem for habilidoso, poderá imaginar um mecanismo responsável pelos fatos que observa, mas nunca poderá ficar completamente seguro de que sua hipótese seja a única possivel. 


\section{DEDICATÓRIA}

Dedico este trabalho a minha família que sempre esteve ao meu lado, me incentivando e apoiando em todos os momentos desta etapa da minha vida.

Aos meus pais, Valdir Pavanelo e Maria de Loudes Guadanholo Pavanelo, pelo amor incondicional e por sempre estarem ao meu lado. Sou fruto dos seus ensinamentos e carrego comigo a educação e a hombridade dos seus conhecimentos e criação. Peço-lhes desculpas por quando não estive presente nos momentos difíceis. Obrigado!

Eu amo vocês!

A minha irmã e "segunda mãe", Elisangela Pavanelo, por estender suas mãos quando precisei, pelo amor e carinho de irmãos que existe entre nós. Você é, sempre foi e continuará sendo um espelho para minha vida. Eu amo você!

A minha sobrinha, Beatriz, que hoje vive linda e tranqüila no ambiente intra-uterino de minha irmã. Estamos te esperando com todo amor e carinho do mundo. 


\section{AGRADECIMENTO ESPECIAL}

A minha orientadora, Profa. Dra. Paula de Carvalho Papa, por dividir seus conhecimentos e ensinamentos, pela orientação e confiança, pelo exemplo de ética e profissionalismo. A você, minha profunda admiração, gratidão e respeito. 


\section{AGRADECIMENTOS}

À Profa. Dra. Maria Angélica Miglino, por me receber e tornar possível o ingresso na Pós-graduação.

Aos professores do Setor de Anatomia da Faculdade de Medicina Veterinária e Zootecnia da Universidade de São Paulo/FMVZ-USP, Pedro Primo Bombonato, José Roberto Kfoury Junior, Francisco Javier $\mathrm{H}$. Blazquez, Antônio Chaves de Assis Neto, pelos ensinamentos e por terem disponibilizado seus laboratórios para execução dos meus experimentos.

Ao Prof. Dr. Alan Peres Ferraz de Melo, pela oportunidade e indicação concedida ao Programa de Pós-Graduação em Anatomia dos Animais Domésticos e Silvestres.

À Profa. Dra. Vanessa Belentani Marques, pela convivência, troca de experiências durante seu trabalho e também pela indicação concedida.

Ao Prof. Dr. Pietro Sampaio Baruselli, pela disponibilidade e por me auxiliar no tratamento e nos exames dos animais deste experimento.

Ao Biólogo e Técnico em Anatomia, Gilmar Rodrigues Lopes, pelo aprendizado de técnicas e pela amizade criada durante bons tempos de experiência profissional.

Aos meus amigos do LEME (Laboratório para Estudos Morfofuncionais e Endocrinologia), Vanessa Uemura da Fonseca, Renata dos Santos Silva, Luciana Alves de Fátima, Liza Margareth M. C. Sousa, Giuliano Gustavo Lesnau, Alex Sander Dias Machado e Juliana S. P. Ferrão, que me auxiliaram na aprendizagem de novas técnicas, pela companhia e amizade de todos os dias.

Aos alunos de Iniciação Científica do LEME, Garros Fontinhas, Felipe Juscele e Jaqueline Hanassaka.

Agradeço também a todos os funcionários da Anatomia da Faculdade de Medicina Veterinária e Zootecnia da Universidade de São Paulo/FMVZ-USP. 
Aos secretários, Jacqkeline e Maicon, pela amizade, educação, simpatia e paciência durante estes anos de convivência.

Aos técnicos Edinaldo (Índio), Ronaldo Agostinho e Diogo Palermo, pela disponibilidade e troca de experiência durante aulas e experimentos.

Aos meus amigos:

Marcos Vinicius Mendes Silva, José Luiz Nogueira, Bruna Nogueira, Thiago Pinheiro Arrais Aloia, Carlos Alberto Palmeira Sarmento, Caio Biase, Marcos Palmeira, Rodrigo Lambert, Evander Bueno, Guilherme Buzon, Dilayla Kelly de Abreu e Renata Avancini Fernandes, Lívia e Kaio Bezerra, Karen Bezerra, Náthia Rigoglio, André Franciolli, Marina Pandolphi Brolio, Marcio Rodrigues, Ana Carolina Mançanares, Phelipe Favaron, Bruno Bertassoli, Paulo Ramos, Franceliusa Delys, Maria Angélica, Maria Vitória Piemonte Constantino, Daniela Moraes de Oliveira e Amilton C. Santos.

Obrigado, de coração, pelo apoio de todos vocês nos momentos difíceis e pelas risadas nos momentos de descontração.

As minhas amigas de Graduação em Ciências Biológicas, Caroline Bonfim e Márcia Maria Urbanin Castanhole.

Aos meus amigos de infância, Rafael Marques dos Santos (Fofão) e Weslei Rigueto Mingorance (Brinca), pelos bons tempos em que crescemos, nos divertimos e sempre que possível, estamos reunidos para cultivarmos esta bela amizade.

A minha turma de amigos da minha infância, André Longui Javareis, Thiago Sufredini Sinibaldi, aos irmãos Brazolin: Matheus e Thiago, Rafael Papandré, Everton César. Todos vocês fizeram muita falta em minha vida nesses últimos anos.

A Bárbara Borges Ferraz pelo carinho e pelos momentos felizes que passamos juntos. 
Aos meus professores de Graduação do Centro Universitário de Rio Preto - UNIRP, pelos ensinamentos e momentos importantes para minha formação acadêmica.

À Faculdade de Medicina Veterinária e Zootecnia da Universidade de São Paulo, por proporcionar infra-estrutura de excelente qualidade para um desenvolvimento científico e profissional adequado.

À CAPES e a FAPESP pelo indispensável apoio financeiro para o meu desenvolvimento cientifico. 


\section{RESUMO}

PAVANELO JUNIOR, V. Expressão do sistema VEGF-A no útero bovino após o tratamento com diferentes doses de eCG. [Expression of VEGF-A system in bovine uterus after treatment with different doses of eCG]. 2012. f76. Dissertação (Mestrado em Ciências) - Faculdade de Medicina Veterinária e Zootecnia, Universidade de São Paulo, São Paulo, 2012.

Protocolos hormonais amplamente utilizados no Brasil em reprodução animal melhoram qualitativa e quantitativamente os rebanhos. Os protocolos de estimulação do folículo dominante e superovulação que utilizam a aplicação dos hormônios folículo-estimulante (FSH) e/ou gonadotrofina coriônica equina (eCG) tem se mostrado eficientes para aumentar a taxa de prenhez e o número de descendentes de alto valor genético, respectivamente. Neste contexto o útero é um órgão essencial para a reprodução em mamíferos e provavelmente alvo destes protocolos. Vários fatores regulam o seu desenvolvimento, como por exemplo, a angiogênese inerente aos órgãos genitais femininos, a implantação e o desenvolvimento da placenta e as ações da progesterona (P4) plasmática. O Fator de Crescimento Endotelial Vascular (VEGF-A) é uma proteína que tem uma função dinâmica de regulação do crescimento vascular endotelial, angiogênese e permeabilidade vascular. Entre os fatores que aumentam a sua expressão, podemos citar os hormônios esteróides ovarianos, as prostaglandinas, o FSH e o próprio eCG. Em geral, estas ações em conjunto estão relacionadas à preparação do ambiente uterino para uma futura prenhez. Deste modo, o objetivo deste trabalho é analisar a expressão do sistema VEGF-A (VEGF-A e seus recpetores FLT-1 e KDR) no útero bovino após o tratamento com diferentes doses de eCG e quantificar as glândulas uterinas presentes nos animais dos diferentes grupos. Para tanto, os animais foram divididos em três grupos: controle, estimulado e superovulado, os quais foram sincronizados e receberam $400 \mathrm{UI}$ (grupo estimulado), $2000 \mathrm{UI}$ (grupo superovulado) ou não receberam eCG (grupo controle). Aos 6 dias após a ovulação, os animais foram abatidos e as amostras coletadas destinadas aos protocolos de imunoistoquímica e PCR em tempo real. Para a estimativa das glândulas uterinas foi utilizado o método morfométrico de contagem. O sistema VEGF-A foi localizado por meio da imunoistoquímica em diferentes tipos celulares, como nos epitélios uterinos e glandulares sem diferenças qualitativas em 
relação aos locais de expressão ou intensidade do sinal positivo. A expressão do mRNA do sistema VEGF-A não apresentou diferença significativa $(P>0,05)$ entre os diferentes grupos. No que se refere à contagem do número de glândulas uterinas, o grupo superovulado apresentou maior quantidade em relação aos grupos controle e estimulado $(P<0,05)$. A correlação entre o mRNA do sistema VEGF-A, a concentração de progesterona plasmática (P4) e o número de glândulas uterinas foi positiva para o Flt-1 com ○ KDR ( $\mathrm{r}=0,60 \mathrm{p}=0,0045)$ e para P4 com as glândulas uterinas $(r=0.74 p=0,0078)$. Assim, podemos inferir que o tratamento com eCG não aumenta a expressão do sistema VEGF-A no útero no dia 6 após a ovulação, mas tem influência no aumento da quantidade de glândulas uterinas.

Palavras-chave: eCG. Útero. Bovino. VEGF-A. Glândulas uterinas 


\section{ABSTRACT}

PAVANELO JUNIOR, V. Expression of VEGF-A system in bovine uterus after treatment with different doses of eCG. [Expressão do sistema VEGF-A no útero bovino após o tratamento com diferentes doses de eCG]. 2012. f76. Dissertação (Mestrado em Ciências) - Faculdade de Medicina Veterinária e Zootecnia, Universidade de São Paulo, São Paulo, 2012.

Hormonal protocols are widely employed in Brazil in the field of animal reproduction improving the herds qualitative and quantitatively. Protocols for stimulation of the dominant follicle and superovulation, which use the application of follicle-stimulating hormone (FSH) and/or equine chorionic gonadotropin (eCG) are efficient methods to increase pregnancy rates and the number of genetically superior descendents, respectively. In this context, the uterus plays an essential role in mammals reproduction and is probably a target of hormonal protocols. Many factors regulate its development, such as angiogenesis, intrinsec to feminine genital organs, implantation and placental development as well as progesterone (P4) actions. The Vascular Endothelial Growth Factor (VEGF-A) is a protein that plays a dynamic role in regulating the vascular endothelial growth, angiogenesis and vascular permeability. Among the factors that increase its expression, the ovarian steroid hormones, prostaglandins, FSH and eCG are of importance. In general, these actions are related and directed to prepare the uterine environment for a future pregnancy. Thus, the objective of this study is to analyze the expression of VEGF-A system (VEGF-A and its receptors FLT-1 and KDR) in bovine uterus after treatment with different doses of $\mathrm{eCG}$ and to quantify the uterine glands in the uterus of different groups. For this purpose, animals were divided into three groups: control, stimulated and superovulated, which underwent estrous synchronization and received $400 \mathrm{IU}$ (stimulated group), $2000 \mathrm{IU}$ (superovulated group) or no eCG (control group). On day 6 post ovulation animals were slaughtered and samples collected and then assigned to immunohistochemistry (IHC) and qPCR. For quantification of the uterine glands the morphometric method of counting was used. VEGF-A system was localized through IHC in different cellular types, as the uterine and glandular epithelia, showing no qualitative differences in relation to site of expression and intensity of the positive signal among the groups. Messenger RNA 
expression of VEGF-A system was not significantly different $(P>0.05)$ either. Regarding the counting of uterine glands, the superovulated group showed increased number compared to stimulated and control groups $(P<0.05)$. The correlation among the mRNA of VEGF-A system, plasma progesterone concentrations and the number of uterine glands was positive when Flt-1 and the KDR $(r=0.60 p=0.0045)$ were correlated and also when P4 and the uterine glands $(r=0.74 p=0.0078)$ were correlated. Thus, we can infer that treatment with eCG did not increase the expression of VEGF-A system in the uterus on day 6 post ovulation, but influences the number of uterine glands.

Keywords: eCG. Uterus. Bovine. VEGF-A. Uterine glands. 


\section{LISTA DE FIGURAS}

Modelo esquemático dos tratamentos utilizados nos animais do grupo controle, estimulado e Figura 1 superovulado. Legenda: $\mathrm{D}=$ dia; $\mathrm{T}$ =tempo; $\mathrm{BE}=$ benzoato de estradiol; PGF $2 \alpha=$ Prostaglandina $\mathrm{F} 2 \alpha ; \mathrm{P} 4=$ progesterona; $\mathrm{n}=$ número de animais.

Esquema do útero bovino. Metodologia utilizada para seleção dos campos de contagem das

Figura 2 glândulas (figura adaptada de Wang et al., 2007). Os quadrados vermelhos representam os campos que foram utilizados para contagem. Abreviaturas: $\mathrm{L}=$ lume; $\mathrm{e}=$ endométrio.

Fotomicrografia do endométrio bovino, com um frame sobreposto para estimar o número de glândulas uterinas $\left(^{*}\right)$. Consideram-se as

Figura 3 estruturas contidas no interior do frame e que não estejam interceptadas pelas linhas de exclusão (linhas cheias).

Expressão do VEGF-A no útero bovino após o tratamento com diferentes doses de eCG $(A, B, C)$. Expressão da proteína VEGF-A no epitélio uterino (seta cheia) dos grupos controle $(A)$, estimulado (B) e superovulado (C). (D, E, F) - Expressão da proteína VEGF-A nas glândulas uterinas (cabeça

Figura 4 de seta) dos grupos controle (D), estimulado (E) e 50 superovulado $(F)$. Presença de vasos sanguíneos em $E$ (seta vazia). Abreviações: $e=$ estroma uterino. $L=$ lume. Inserts em $A$ e $D$ controle negativo. Barra: 50um.

Expressão do Flt-1 no epitélio uterino e glandular nos grupos controle (A), estimulado (B) e superovulado (C). (D, E, F) - Glândulas uterinas (cabeça de seta) com a expressão do Flt-1 nos

Figura 5 grupos controle (D), estimulado (E) e superovulado $(F)$. Abreviações: $e=$ estroma uterino. $L=$ lume. Inserts em A e D = controle negativo. Barra 50 um. 
Expressão do KDR no epitélio uterino (seta cheia) e nas glândulas uterinas (cabeça de seta) nos grupos controle (A), estimulado (B) e superovulado (C). Expressão KDR nas glândulas uterinas (cabeça de seta) e nos vasos sanguíneos (seta Figura 6 vazia) nos grupos controle (D), estimulado (E) e superovulado (F). Abreviações: $\mathrm{e}=$ estroma uterino. $L=$ lume. Inserts em $A$ e $D=$ controle negativo. Barrra $=50$ um.

A expressão do mRNA do Sistema VEGF-A nos cornos uterinos ipsolateral e contralateral dos animais dos grupos controle (A) e estimulado (B). Figura 7 Não foi observada diferença significativa $(P>$ $0,05)$. Os dados estão expressos em média \pm EPM.

Expressão do RNAm VEGF (A), Flt-1 (B) e KDR (C) no endométrio dos animais dos grupos

Figura 8 controle, estimulado e superovulado. Não foi observada diferença significativa $(P>0,05)$. Os dados estão expressos em média \pm EPM.

Densidade glandular (número de glândulas por $\mathrm{mm}^{2}$; A) e número total de glândulas uterinas (B) nos animais dos grupos controle, estimulado

Figura 9 e superovulado. Os resultados estão expressos em média +/- EPM. Letras diferentes apresentaram diferença significativa $(P<0,0001)$. 


\section{LISTA DE TABELAS}

Valores de Concentração de progesterona plasmática total nos animais dos grupos controle $(n=5)$,

Tabela 1 estimulado $(n=6)$ e superovulado $(n=7)$. (a) média dos valores de progesterona de todos os animais do grupo; (b) desvio padrão da média.

Correlação entre a expressão gênica do sistema Tabela 2 VEGF-A, a progesterona plasmática e o número de glândulas uterinas. 


\section{LISTA DE QUADROS}

Quadro 1. Detalhes dos anticorpos primários para Quadro 1 imunoistoquímica.

Quadro 2. Seqüência dos oligonucleotídeos iniciadores e sondas utilizadas para a amplificação do VEGF-A, FIt-

Quadro 2 1, KDR e tubulina, $S=$ sense e $A$ = anti-sense. 


\section{SUMÁRIO}

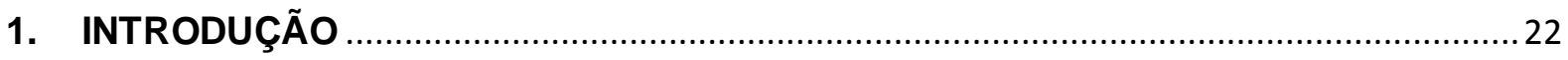

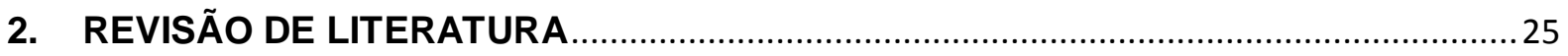

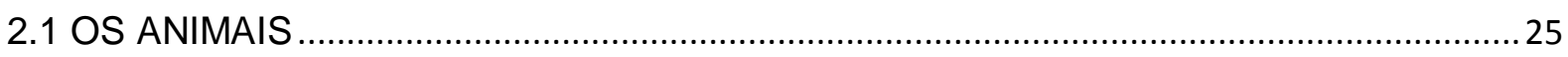

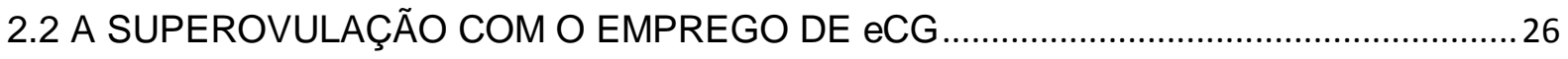

2.3 A ESTIMULAÇÃO DO FOLÍCULO DOMINANTE COM O EMPREGO DO eCG .............28

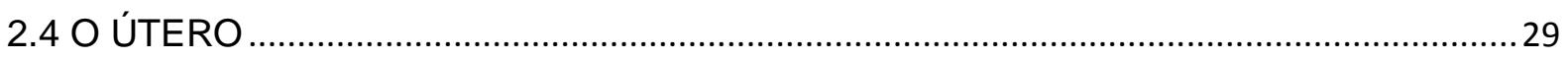

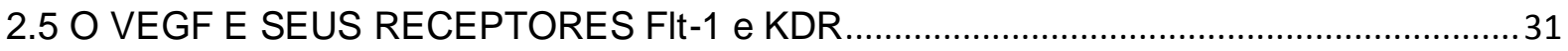

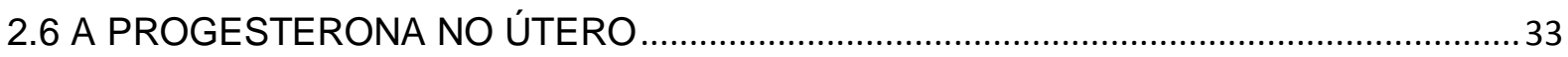

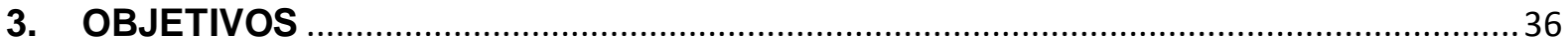

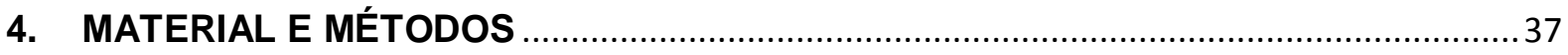

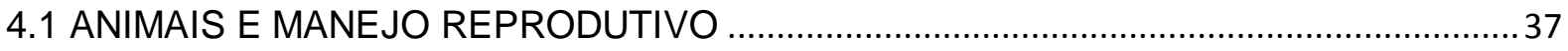

4.2 COLETA DE AMOSTRAS PARA IMUNOISTOQUÍMICA ............................................... 40

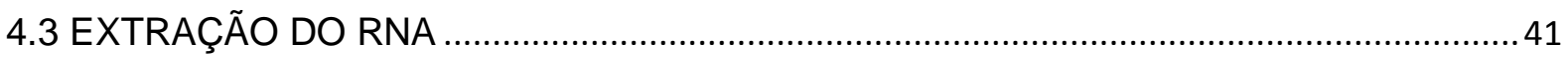

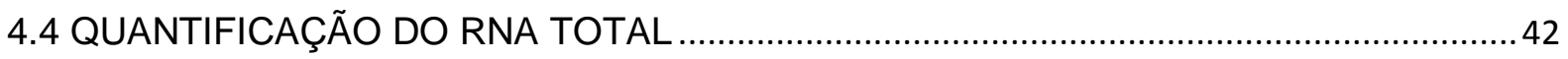

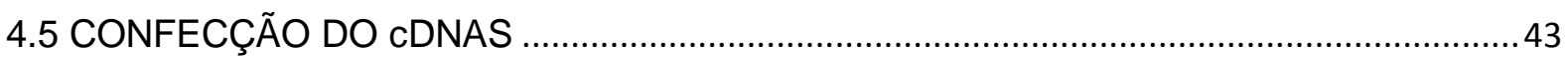

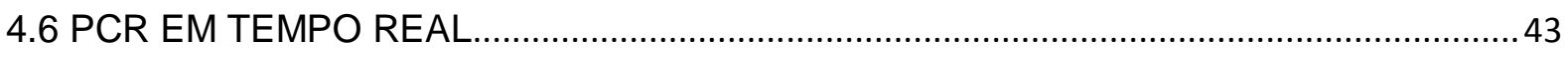

4.7 ESTIMATIVA DA DENSIDADE DO NÚMERO DE GLÂNDULAS UTERINAS..................46

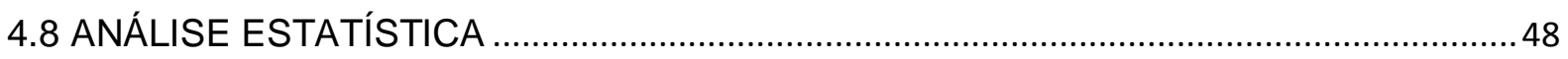

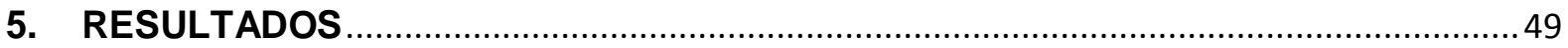

5.1 IMUNOLOCALIZAÇÃO DO SISTEMA VEGF NO ÚTERO DE BOVINOS ….....................49

5.2 EXPRESSÃO GÊNICA DO SISTEMA VEGF-A NO ENDOMÉTRIO BOVINO .................53

5.3 ESTIMATIVA DA DENSIDADE DO NÚMERO DE GLÂNDULAS UTERINAS.................56

5.4 - CONCENTRAÇÃO DA PROGESTERONA PLASMÁTICA..............................................57 
5.5 ANÁLISE DE CORRELAÇÃO DA PROGESTERONA PLASMÁTICA COM OS

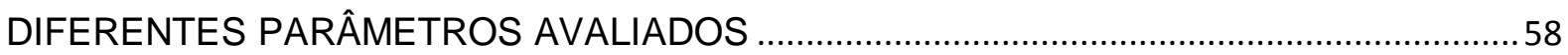

6. DISCUSSÃO

7. CONCLUSÕES

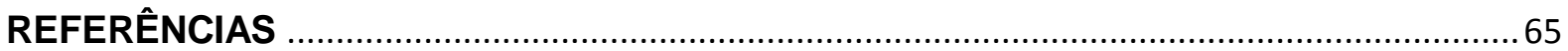




\section{INTRODUÇÃO}

Na reprodução animal são aplicadas biotecnologias com o intuito de melhorar qualitativa e quantitativamente os rebanhos. As técnicas mais utilizadas no manejo reprodutivo são: sincronização de cio, inseminação artificial em tempo fixo (IATF), superovulação, produção de embriões in vitro seguida de transferência de embriões (REICHENBACH et al., 2002), além da estimulação do folículo dominante (SALES et al., 2011).

Assim, nos tratamentos superovulatórios, fêmeas de comprovada qualidade genética são tratadas com hormônios gonadotróficos e seus oócitos são fecundados in vivo ou in vitro; os embriões resultantes são transferidos para receptoras, mães substitutas com potencial genético inferior. O objetivo do tratamento é fornecer àqueles folículos que normalmente se tornariam atrésicos, um meio hormonal adequado para que continuem seus processos de maturação, culminando com a ovulação (DINIZ et al., 1999).

Os principais hormônios aplicados diretamente na superestimulação ovariana são: o FSH (hormônio folículo-estimulante), LH (hormônio luteinizante), gonadotrofina coriônica humana ( $\mathrm{hCG}$ ) (HERR et al., 2004) e a gonadotrofina coriônica equina (eCG) (HASLER, 2001; BARUSELLI et al., 2004a), sendo estes bastante utilizados nas medicinas humana e veterinária, respectivamente, para mimetizar os mecanismos endócrinos que regulam os ciclos reprodutivos (HERVÉ et al., 2006).

O tratamento com $\mathrm{GnRH}$ resulta na ovulação do folículo dominante e a emergência de uma nova onda folicular 1 ou 2 dias mais tarde (PURSLEY; MEE; WILTBANK, 1995). Na tentativa de melhorar a sincronização do estro e aumentar o número de receptoras apropriadas para receber os embriões produzidos in vitro, com base em protocolos, foram desenvolvidos o uso exógeno de P4, eCG e benzoato de estradiol e estes têm sido utilizados com grande sucesso em programas de transferência de embriões (SIQUEIRA et al., 2009).

O útero pertence aos órgãos genitais femininos (NAV, 2005), cuja principal função é o favorecimento do desenvolvimento do embrião, sua implantação, crescimento do feto durante a gestação e parto (HAFEZ, 2004). Ele passa por 
grandes variações de acordo com a idade do animal ou devido à ocorrência de gestações. O microambiente uterino é responsável pela síntese de moléculas secretadas pelo concepto e endométrio (ASSELIN; FORTIER, 2000), oriundas da circulação que fornecem nutrientes e o meio físico-químico adequado para o desenvolvimento do embrião, desde sua chegada ao útero, até a sua implantação e posterior desenvolvimento (SPENCER; GRAY, 2006).

Assim, as ações dos esteróides ovarianos causam mudanças cíclicas em inúmeras respostas uterinas, como no fluxo sanguíneo (FORD; CHENAULT; ECHTERNKAMP, 1979), na histologia, citologia endometrial (MARINOV; LOVELL, 1968; PRIEDKALNS, 1976) e no perfil protéico do fluido uterino (ROBERTS; PARKER, 1976). Essas alterações no útero ocorrem devido ao requerimento biológico para estabelecer um ambiente intrauterino capaz de sustentar o concepto bovino (SREENAN, 1978).

Além disso, alterações que envolvem o desenvolvimento e regeneração do útero estão relacionadas às glândulas uterinas, que secretam e sintetizam um conjunto de substâncias e proteínas denominado histotrófo. O histotrófo auxilia nos sinais de reconhecimento da prenhez, desenvolvimento e crescimento da placenta e do feto em suínos, ovinos, primatas e humanos (BAZER, 1975; SPENCER; GRAY, 2006). Em geral, o desenvolvimento das glândulas uterinas está associado a um melhor ambiente uterino para a implantação e o desenvolvimento do concepto.

A progesterona (P4) desempenha um papel fundamental nos eventos reprodutivos associados com o estabelecimento e a manutenção da gestação e com a regulação da função endometrial. Dentre essas relações, incluem-se as interações materno-fetais e receptividade do útero para a implantação (DISKIN; MURPHY; SREENAM, 2006; DISKIN; MORRIS, 2008). Uma proporção considerável de perda de embriões pode ser atribuída às baixas concentrações de P4 circulante (DISKIN; MORRIS, 2008). Além disso, úteros submetidos a elevadas concentrações de P4 previamente à implantação favorecem o desenvolvimento embrionário (CLEMENTE et al., 2009; BARUSELLI et al., 2011).

Alguns trabalhos demonstram a influência da administração de gonadotrofina coriônica eqüina (eCG) na formação e vascularização do corpo lúteo, produção de progesterona e fluxo sanguíneo uterino, tanto em vacas receptoras (estimulação do 
folículo dominante) como também em doadoras (superovulação) (FUCK et al., 2002; BARUSELLI et al., 2004b; HONNENS et al., 2008).

O Fator de Crescimento Endotelial Vascular (VEGF) é uma proteína que tem uma função dinâmica de regulação do crescimento vascular endotelial, angiogênese e permeabilidade vascular (FERRARA et al., 1998). Entre os fatores que aumentam a sua expressão, podemos citar os hormônios esteróides ovarianos (HYDER, 2002), as prostaglandinas (GATELY, 2000), o FSH (PAPA et al., 2007), o hCG (FILICORI et al., 2005) e o próprio eCG (SHIMIZU et al., 2002).

O VEGF é expresso no endométrio (SMITH, 2001), sendo um fator importante na regulação dos eventos de implantação e início do estabelecimento da placenta (MATSUMOTO et al., 2002), proliferação das células endoteliais dos vasos sanguíneos, formação e função vascular (SMITH, 1998; SMITH, 2001). Alterações na expressão do sistema VEGF estão associadas a disfunções ovarianas e uterinas (FERRARA et al., 2003a).

Atualmente, técnicas de biologia molecular permitem descobertas na área de reprodução animal visando melhorar a eficiência reprodutiva das fêmeas bovinas. Deste modo, identificar a expressão gênica e protéica do sistema VEGF-A, bem como possíveis alterações no endométrio de animais tratados com diferentes doses de eCG é importante para melhor compreensão da morfofisiologia da reprodução. 


\section{REVISÃO DE LITERATURA}

Neste capítulo serão abordados conceitos importantes referentes aos animais utilizados no experimento, protocolos de superovulação e estimulação do folículo dominante com ênfase na utilização do eCG, a expressão do VEGF-A e de seus receptores Flt-1 e KDR no útero e a ação da progesterona nas glândulas uterinas. Entendemos que a apresentação destes se faz necessária para uma explanação dos conceitos em relação aos assuntos abordados.

\subsection{OS ANIMAIS}

A utilização das biotecnologias aplicadas à reprodução permite maximizar o uso de material genético para a obtenção de animais com excelente ganho de peso e boa qualidade de carcaça. Por sua grande extensão, o Brasil tem potencial para aumentar a produção da bovinocultura de carne, sendo que o aumento da produtividade pode ser obtido com o emprego de biotecnologias que aperfeiçoam 0 sistema de produção e a reprodução, tendo em vista que somos um dos maiores produtores e exportadores de carne bovina do mundo (FAO, 2010).

Segundo Montiel e Ahuja (2005), os principais fatores que comprometem a reprodução são a condição nutricional e a amamentação. Quanto à nutrição, sabemos que animais criados em regiões tropicais apresentam comprometimento na atividade ovariana pós-parto, devido principalmente ao inadequado conteúdo energético fornecido pelas pastagens. Dessa maneira, a energia ingerida pelo animal é priorizada para funções vitais de manutenção e da produção de leite, em detrimento das funções reprodutivas. Já a amamentação reduz a liberação de GnRH (hormônio liberador de gonadotrofina) e a secreção de LH (hormônio luteinizante) (WILLIAMS, 1990). 
Entretanto, ressaltam-se algumas diferenças relacionadas à fisiologia reprodutiva de vacas Bos taurus em comparação ao Bos indicus (espécie predominantemente criada no Brasil com finalidade de produção de carne); as primeiras apresentam maior sensibilidade às gonadotrofinas, tempo menor de duração do estro, o qual é frequentemente expresso durante a noite (BÓ; BARUSELLI; MARTINEZ, 2003) e apresentam folículo dominante com maior diâmetro (BARUSELLI et al., 2011).

Assim, o conhecimento das particularidades da fisiologia reprodutiva de $B$. indicus e de $B$. taurus para empregar biotécnicas que buscam a multiplicação de indivíduos geneticamente superiores e a melhoria da eficiência reprodutiva (WILLIAMS et al., 1996), bem como a análise das conseqüências destes tratamentos nos órgãos genitais destas fêmeas, são importantes para otimizar os processos produtivo e reprodutivo dos rebanhos em nosso país.

\subsection{A SUPEROVULAÇÃO COM O EMPREGO DE eCG}

A superovulação é uma técnica utilizada para estimular o crescimento e a múltipla ovulação dos folículos antrais, através da administração de gonadotrofinas exógenas (ADAMS, 1994). Nos tratamentos com altas doses de eCG, fêmeas de qualidade genética superior são superovuladas com hormônios gonadotróficos e seus oócitos são fecundados in vivo ou in vitro, sendo que, os embriões resultantes são transferidos para as receptoras, mães substitutas com potencial genético inferior (HAFEZ, 2004).

Os principais hormônios aplicados diretamente na superestimulação ovariana são: o FSH, LH, hCG (HERR et al., 2004) e o eCG (SOUMANO; PRICE, 1997; SÁ FILHO et al., 2010). Folículos em vários estágios de desenvolvimento estão normalmente presentes nos ovários. O objetivo do tratamento superovulatório é fornecer àqueles folículos, que normalmente se tornariam atrésicos, um meio hormonal adequado para que continuem seus processos de maturação, resultando na ovulação (DINIZ et al., 1999). As gonadotrofinas estimulam o crescimento dos 
folículos pequenos, revertendo a atresia dos folículos acima de 1,7mm (MOOR; KRUIP; GREEN, 1984).

O eCG é um fármaco de meia vida longa (até 3 dias), produzido nos cálices endometriais da égua prenhe (40 a 130 dias) (MURPHY; MARTINUK, 1991), que se liga aos receptores de FSH e LH dos folículos e aos receptores de $\mathrm{LH}$ do corpo lúteo (STEWART; ALLEN, 1981; CAVALIERI et al., 1997; PEGORER et al., 2011). Em eqüinos, o eCG resulta na ovulação ou luteinização de folículos durante a gestação, com conseqüente aumento da progesterona circulante (MURPHY; MARTINUK, 1991; BARUSELLI et al., 2004b; PEGORER et al., 2011).

O eCG é formado por duas subunidades ( $\alpha$ - composta por 96 aminoácidos; e $\beta$ - composta por 149 aminoácidos). Uma característica importante da molécula de eCG é a existência da grande quantidade de carboidratos (aproximadamente $45 \%$ de sua massa), principalmente a $\mathrm{N}$-acetil neuramina, ou ácido siálico, primordialmente presente na subunidade $\beta$ da molécula de eCG, o que proporciona uma grande meia vida a este composto químico (MURPHY; MARTINUK, 1991). Ainda, devido ao alto peso molecular e à presença de ácido siálico, a molécula de eCG é carregada negativamente, o que dificulta a sua filtração glomerular e aumenta ainda mais sua meia-vida. Devido a todos estes fatores, a meia-vida do eCG quando aplicado em bovinos é considerada longa (SOUZA et al., 2009).

De acordo com Baruselli et al. (2004a), o eCG, quando administrado nas vacas em anestro, cria condições para estimular o crescimento folicular e a ovulação, mesmo em vacas que tenham comprometimento na liberação de gonadotrofinas. Seu uso tem apresentado efeito positivo em rebanhos com baixa taxa de ciclicidade (anestro), em animais recém-paridos (período pós-parto inferior a 2 meses) (BARUSELLI et al., 2004b) e aumenta a taxa de prenhez (MARQUES et al., 2005). Ainda, devido a sua ação mimetizar as ações de LH e FSH e sua meia vida ser longa (três dias), o eCG pode ser utilizado em dose única nos protocolos para superovulação em bovinos (BARUSELLI et al., 2008).

Assim, a hiperestimulação ovariana provoca alterações morfológicas e funcionais importantes no $\mathrm{CL}$ (corpo lúteo) e, consequentemente, no ambiente uterino. O estabelecimento e a manutenção da gestação, bem como o crescimento embrionário em bovinos, estão correlacionados à habilidade do CL em secretar P4 
(FIELDS; FIELDS, 1996), hormônio intimamente relacionado com o ambiente tubário e uterino.

\subsection{A ESTIMULAÇÃO DO FOLÍCULO DOMINANTE COM O EMPREGO DO eCG}

O emprego do eCG também tem sido relatado em receptoras de embrião, que recebem eCG durante o tratamento de sincronização apresentando um aumento na taxa de ovulação e de aproveitamento, além de possuírem maiores níveis de progesterona circulante no diestro (BARUSELLI et al., 2000), minimizando falhas no reconhecimento da gestação e aumentando a eficiência da transferência de embriões (BINELLI, 2001).

Diversos autores consideram o uso do eCG como uma ferramenta para melhorar as concentrações plasmáticas de P4 durante o ciclo estral (FUENTES; DE LA FUENTES, 1997; BARUSELLI et al., 2000) podendo atuar de forma diferente dependendo do período estral que se inicia o tratamento (SÁ FILHO et al., 2010).

Assim, a estimulação com a utilização do eCG causa um aumento folicular associado a um acúmulo de expressão do mRNA de proteínas que são importantes para a produção de pregnenolona, proporcionando maior quantidade dos precursores de progesterona. Há abundância de mRNA de StAR em folículos médios e grandes que receberam estimulação com eCG (SOUMANO; PRICE, 1997). Além disso, foi observado aumento da expressão gênica e protéica da proteína StAR no corpo lúteo dos animais estimulados e superovulados seguido pelo aumento na produção de progesterona por corpo lúteo dos animais estimulados (FÁTIMA, dados não publicados).

Os resultados da estimulação com eCG, quando comparados com os de $\mathrm{FSH}$, são duas vezes maiores em relação ao crescimento folicular, ovulação e concepção dos animais, devido ao seu tempo de atuação no organismo que é de 3 dias, enquanto que com o FSH é de apenas alguns minutos (SALES et al., 2011).

Bó et al (2002) verificaram que a utilização de 400UI de eCG no momento da emergência da onda de crescimento folicular determinou apenas $2 \%$ de dupla 
ovulação em receptoras, no entanto, esse tratamento formou corpos lúteos únicos, maiores e incrementou a taxa de concepção e de prenhez. Posteriormente, Reis et al (2004) demostraram que a dose de 400UI de eCG é suficiente para obtenção de resultados satisfatórios em vacas receptoras.

\subsection{O ÚTERO}

O útero é um dos órgãos genitais femininos, cuja principal função é o desenvolvimento do embrião, sua implantação e crescimento do feto durante a gestação até o parto (LEE; DEMAYO, 2004). Assim, tendo em vista a base teórica para o desenvolvimento desse trabalho, faz-se a descrição de pontos importantes da anatomia, composição e função do órgão.

Nos bovinos, o útero é composto de dois cornos uterinos (útero bicórneo assim como nos ovinos e equinos), um corpo e uma cérvix (colo), e apresenta um septo (véu uterino - NAV, 2005) que separa os dois cornos do corpo uterino, tendo as margens uterinas unidas à parede pélvica e abdominal pelo ligamento largo do útero (HAFEZ, 2004).

A vascularização do útero é realizada por três vasos arteriais. A artéria ovárica emerge diretamente da aorta, é relativamente pequena e supre o ovário, a tuba uterina e o corpo do útero. Sua divisão uterina anastomosa-se com os ramos da a. uterina, a qual se origina da a. ilíaca interna e emite três ramos para todo o órgão. Outro vaso que faz a irrigação deste órgão é a a. vaginal que emite ramificações para o útero. A drenagem sanguínea do útero é composta por um conjunto de três veias: veia vaginal (duas em cada margem uterina), v. ovárica e v. vaginal acessória (DYCE; SACK; WENSING, 2010).

Segundo Di Dio (2002), o útero possui inervação dos nervos simpáticos e parassimpáticos que suprem todos os órgãos genitais e ligamentos como 0 ligamento largo do útero, ligamento redondo do útero e ligamento intercornual que auxiliam a fixação e sintopia entre os órgãos.

A parede uterina é relativamente espessa e formada por três camadas 
(HAFEZ, 2004). Externamente há uma serosa, em seguida, o miométrio (camada mais profunda) constituído de musculatura lisa e a camada mais interna chamada de endométrio ou mucosa uterina que envolve a cavidade luminal e contém internamente um epitélio colunar simples junto a áreas de epitélio colunar pseudoestratificado (ASGERALLY; FAZLEABAS; STRAKOVA, 2002).

De acordo com Junqueira e Carneiro (2004), o endométrio consiste em um epitélio e uma lâmina própria que contém glândulas tubulares simples que às vezes se ramificam nas porções mais profundas (próximo ao miométrio). O epitélio uterino é do tipo colunar simples e constituído por células ciliadas e secretoras. $O$ endométrio pode ser subdividido em duas camadas, basal e funcional. A camada basal é adjacente ao miométrio e a camada funcional sofre mudanças intensas durante os ciclos estrais (CHEN et al., 2009). Elas são irrigadas por vasos provenientes do miométrio, sendo que as artérias retas irrigam a camada basal e as artérias espiraladas irrigam a camada funcional (JUNQUEIRA; CARNEIRO, 2004).

Apoiadas sobre seu epitélio simples, as glândulas endometriais tem características tubulares, possuem um lume que, na fase secretora, torna-se mais amplo, porque nesta fase, o endométrio uterino metaboliza carboidratos, lipídios e proteínas para suprir os requerimentos necessários à nutrição celular, rápida proliferação do tecido uterino e para o desenvolvimento do concepto. Essas reações dependem de ações enzimáticas envolvidas no metabolismo da glicose, aumento da circulação através de arteríolas espiraladas. Alterações morfológicas que ocorrem no endométrio e no miométrio que são estimuladas por hormônios ovarianos dentre outros. Vale ressaltar que o endométrio e seus fluidos têm importância no processo reprodutivo: transporte dos espermatozóides, regulação da função do CL, início da implantação, gestação e parto (UGUR et al., 2006).

Falhas na interação entre hormônios esteróides e o útero resultam em altos índices de perda embrionária nas fêmeas bovinas. Cerca de 30 a $40 \%$ dessas falhas representam grande limitação biológica para que se atinjam índices reprodutivos satisfatórios (DISKIN; SCREENAN, 1980; HUMBLOT, 2001; SANTOS; DEAN, 2004).

Durante a implantação e o futuro crescimento e desenvolvimento do embrião, a receptividade uterina é mediada por hormônios esteróides, sendo a ação da P4 
mais importante para interações materno-fetais e regulação da função endometrial (ING; TORNESI, 1997).

\subsection{O VEGF E SEUS RECEPTORES Flt-1 e KDR}

O Fator de Crescimento Endotelial Vascular (VEGF-A) é o fator de crescimento que atua de forma parácrina, responsável pelo desenvolvimento dos vasos sanguíneos, bem como a migração de células endoteliais. A produção e a expressão do VEGF-A no útero são essenciais para um bom desenvolvimento reprodutivo (GEVA; JAFFE, 2000). Sua atuação em associação com hormônios esteróides tem efeitos locais na angiogênese para um bom desenvolvimento do endométrio uterino (HYDER et al., 1996; FERRARA et al., 2003a) .

O VEGF-A é um importante regulador do desenvolvimento tanto da angiogênese como da vasculogênese embrionária de camundongos. Ele também está envolvido no crescimento do esqueleto, na formação óssea endocondral e na angiogênese das glândulas endócrinas (FERRARA, et al., 2003a; FERRARA, 2004).

Em fêmeas, o VEGF-A desempenha um papel importante no crescimento dos folículos ovarianos e no desenvolvimento e manutenção do corpo lúteo (CL) pela mediação de angiogênese no ovário. Defeitos na angiogênese podem causar alguns transtornos, como involução ovariana, perda da gestação, síndrome de hiperestimulação ovariana e neoplasias de ovário (GEVA; JAFFE, 2000). ARTAC et al., (2009) demonstraram que o VEGF-A está envolvido na ativação, maturação e sobrevivência de folículos primordiais. Hervé et al (2006) relataram em seu trabalho que a variabilidade na expressão do sistema VEGF-A está associada a alterações funcionais no útero e nos ovários.

A família do VEGF é composta por cinco membros, incluindo VEGF-A, VEGFB, VEGF-C, VEGF-D e o fator de crescimento placentário (PIGF) (TAMMELA et al., 2005). Nos seres humanos, existem pelo menos oito isoformas do VEGF-A (VEGF121, VEGF145, VEGF148, VEGF165, VEGF165b, VEGF183, VEGF189 e VEGF206) que são geradas por derivação alternativa de um único gene (NOWAK et al., 2008). A nomenclatura utilizada para as diferentes isoformas é baseada na 
quantidade de aminoácidos que cada molécula de proteína secretada possui (BATES; HARPER, 2002; LANGE et al., 2003; HARPER; BATES, 2008; NOWAK et al., 2008), definindo também características, como a capacidade de ligação a heparina e sua solubilidade (PARK et al., 1994; POLTORAK et al., 1997). Já, a proteína VEGF bovina possui cinco isoformas, entretanto, três delas (VEGF 120, VEGF 145 e VEGF 165) são solúveis e exercem seus efeitos de forma parácrina, enquanto as duas maiores isoformas (VEGF 188 e VEGF 205) estão associados à membrana celular e atuam de forma autócrina (FERRARA et al., 1992; NG; KRILLEKE; SHIMA, 2006).

O VEGF- A164 (para camundongos, ratos) ou 165 (para humanos, bovinos) é a isoforma predominante do VEGF-A. Atua na permeabilidade vascular e estimula a migração de células endoteliais (mitogênico para estas células) (NAGY et al., 2002).

Entre os fatores que aumentam a expressão do VEGF, podemos citar os hormônios esteróides ovarianos (HYDER, 2002) e as prostaglandinas (GATELY, 2000). O VEGF é expresso no endométrio (SMITH, 2001), sendo um fator importante na regulação dos eventos de implantação e início do estabelecimento da placenta (MATSUMOTO et al., 2002).

O crescimento cíclico do endométrio depende da proliferação capilar e do aumento no fluxo sanguíneo causado por vasodilatação e alterações na permeabilidade vascular (GIUDICE, 1996). Essas mudanças são reguladas por E2 e P4 através da ativação de seus receptores (PERROT-APPLANAT et al., 1994, LECCE et al., 2001), essenciais para o desenvolvimento da vascularização uterina durante a angiogênese (HERYANTO; LIPSON; ROGERS, 2003).

Existem dados de camundongos knock-out para o sistema VEGF (FERRARA et al., 1996) que não produziram descendentes viáveis. Embriões com inativação funcional de um alelo do VEGF mostram várias malformações no sistema vascular, resultando na letalidade nos dias 11 e 12 de gestação, sugerindo um regulamento dose dependente do desenvolvimento vascular pelo VEGF (SHALABY et al., 1995).

O VEGF age através dos receptores, O VEGFR-1/FIt-1 (Fms-like tyrosine kinase - 1) e o VEGFR-2/KDR (Kinase insert domain containing region). O principal mediador da ação mitogênica e angiogênica, proliferação de células endoteliais e permeabilidade vascular do VEGF-A é o VEGFR-2 (FERRARA; GERBER; LECOUTER, 2003b). 
Assim, o VEGF-A e seus receptores, Flt-1 e KDR, foram localizados no epitélio uterino e nos trofoblastos, bem como no tecido vascular e glândulas uterinas. A presença do sistema VEGF-A na interface maternofetal e na vascularização mostra que o VEGF-A bovino apresenta funções na angiogênese e permeabilidade vascular, atividade de fator de crescimento facilitando trocas maternofetais via ação parácrina, propriedade quimiotática no endotélio capilar, influencia de forma autócrina a migração de células trofoblásticas gigantes (PFARRER et al., 2006) e ação modulatória na função trofoblástica (DANTZER; WINTHER, 2001), além de agir também influenciando a esteroidogênese (CAMPOS, 2005; SOUSA, 2007).

Segundo Sagsoz e Saruhan (2011), o VEGF no útero está relacionado a fatores que podem mediar o estabelecimento de um ambiente uterino adequado e a oferta nutricional ao embrião através da angiogênese e o aumento da atividade secretora das células epiteliais.

\subsection{A PROGESTERONA NO ÚTERO}

A progesterona (P4) desempenha funções importantes na regulação de vários fenômenos fisiológicos relacionados ao crescimento normal, desenvolvimento e reprodução dos animais domésticos.

A P4 regula a função reprodutiva através de dois receptores intracelulares que pertencem a uma superfamília de receptores nucleares, na qual estão inclusos não só receptores esteróides, mas também os de Vitamina $D$, hormônio da tireóide e receptores órfãos (CARSON-JURICA; SCHRADER; O'MALLEY, 1990; TSAl; O'MALLEY, 1994; KUMAR et al., 2003).

Existem duas formas de receptores de $\mathrm{P} 4$ que diferem em suas atividades funcionais. Eles são divididos em receptor de P4 A (PR-A) e B (PR-B). Ambas as isoformas são co-expressas na maioria dos tecidos alvo e a razão de existirem duas formas de receptores de P4 é a função exercida de acordo com o tipo celular onde atuam (LI; O'MALLEY, 2003). Alguns autores (RICHER et al., 1998; OGLE, 2002) relatam um terceiro tipo de receptor para $\mathrm{P} 4 \mathrm{em}$ alguns tecidos e células deciduais (receptor C). 
Os receptores PR-A e PR-B são ativados a partir da dissociação e dimerização de moléculas da proteína chaperone, seguido de uma ligação do complexo esteróide-receptor geralmente localizado na região promotora do gene (TSAI; O’MALLEY, 1994; KUMAR et al., 2003).

Foi descrito em camundongos knock-out para PR-A e PR-B que os receptores $A$ desempenham um papel importante na mediação de ações da P4 no útero e ovário, enquanto que os receptores $B$ têm atuação no desenvolvimento das glândulas mamárias (MULAC-JERICEVIC et al., 2000; 2003). A ativação dos receptores de P4 ocorre pela via MAPK que age estimulando o ciclo de mitoses nas células (BOONYARATANAKORNKIT et al., 2007).

Em geral, as ações da P4 no útero estão relacionadas à preparação do mesmo para o desenvolvimento do concepto. No endométrio, a P4 induz diferenciação das células do estroma, estimula a secreção glandular, promove acúmulo de vacúolos basais no epitélio glandular (MASLAR; POWERSCRADDOCK; ANSBACHER, 1986), altera o padrão de secreção das proteínas das células endometriais e induz ao relaxamento do miométrio (BRATTA; CECI; LOIZZI, 1996). A P4 ainda promove uma diminuição na regulação da expressão dos genes que regulam os canais dependentes de cálcio, dificultando a entrada de cálcio na célula (TEZUCA et al., 1995). Desta maneira, as ações da P4 promovem condições essenciais no desenvolvimento uterino para uma futura prenhez.

O endométrio consiste em um epitélio e estroma subjacente, além de tecido conjuntivo frouxo, células do sistema imunológico e elementos vasculares. No estroma uterino, estão presentes glândulas endometriais que desembocam no lume uterino. As glândulas uterinas originam-se a partir de invaginações do epitélio luminal e crescem no estroma subjacente (GRAY et al., 2001; SPENCER; BAZER, 2004).

Durante o ciclo estral, as glândulas uterinas se apresentam não ramificadas, baixas e com pouca secreção. À medida que aumentam os níveis de P4 circulante, elas crescem, tornam-se mais sinuosas e complexas (SPENCER; BAZER, 2004).

$\mathrm{Na}$ maioria das espécies domésticas, o desenvolvimento das glândulas uterinas (adenogênese) inicia-se durante as duas primeiras semanas de vida pósparto e sua exposição, nesta idade, a hormônios esteróides causa infertilidade nos animais adultos. Entretanto, a P4 no útero de animais adultos tem efeito no aumento 
das taxas de concepção e desenvolvimento uterino (BARTOL et al., 1988; BARTOL et al., 1999). 


\section{OBJETIVOS}

Para testar a hipótese de que o tratamento com eCG aumenta a expressão do sistema VEGF-A no útero e altera a morfologia do endométrio, os seguintes objetivos específicos foram determinados:

- Quantificar a expressão gênica do VEGF-A e seus receptores, Flt-1 e $\mathrm{KDR}$, no endométrio de animais submetidos aos protocolos de estimulação e superovulação com eCG comparando-os aos animais controle;

- Avaliar a distribuição espacial do sistema VEGF-A no útero dos animais tratados ou não com eCG;

- Quantificar e comparar a densidade de glândulas uterinas presentes nos animais estimulados e superovulados em relação aos animais do grupo controle;

- Correlacionar os dados da expressão gênica do sistema VEGF-A e da densidade de glândulas uterinas com as concentrações plasmáticas de progesterona. 


\section{MATERIAL E MÉTODOS}

\subsection{ANIMAIS E MANEJO REPRODUTIVO}

Os animais foram procedentes da Prefeitura do Campus de Pirassununga (PCAPS) da Universidade de São Paulo e constituíam um grupo de descarte do rebanho de gado de corte do referido Campus. Após a fase experimental, os animais foram abatidos no abatedouro escola do Campus de Pirassununga, o útero foi coletado e a carcaça destinada ao consumo humano.

Para realização dos experimentos foram utilizados úteros de 11 animais divididos em 3 grupos:

$\checkmark$ Grupo controle - animais sincronizados $(n=3)$;

$\checkmark$ Grupo estimulado - animais tratados com eCG (400Ul/animal) no dia 8 após a sincronização $(n=5)$.

$\checkmark$ Grupo superovulado - animais tratados com eCG (2000Ul/animal) no dia 4 após a sincronização $(n=3)$.

O tratamento de sincronização do cio foi iniciado com a utilização de $2 \mathrm{mg}$ de benzoato de estradiol $(\mathrm{BE})+$ implante de progesterona (P4) no dia 0; o tratamento superovulatório ocorreu com a aplicação de 2000Ul de eCG no dia 4. Uma dose de PGF2 $\alpha$ foi administrada no dia 6 pela manhã e o dispositivo de progesterona retirado 36 horas após a dose de PGF2 $\alpha$, momento no qual foi administrada outra dose de PGF2 $\alpha$. A indução da ovulação foi realizada com $\mathrm{GnRH}$, administrado 12 horas após a remoção do dispositivo de $\mathrm{P} 4$.

Nos animais dos grupos controle e estimulado, ou seja, no protocolo de sincronização do ciclo estral sem e com administração de eCG respectivamente, as condições de sincronização foram as mesmas utilizadas no protocolo de superovulação, salvo o tempo de retirada do dispositivo de P4 que foi no dia 8 e a 
administração de GnRH 48 horas após a retirada da P4 junto com a aplicação de $400 \mathrm{UI}$ de eCG. Estas diferenças se justificam devido à utilização de protocolos amplamente estabelecidos, nos quais estas diferenças são aplicáveis para uma resposta equivalente. Como já é sabido, o objetivo do tratamento de superestimulação ovariana é o recrutamento de vários folículos para que se tornem pré-ovulatórios e ovulem em um único ciclo estral. A taxa de crescimento de folículos múltiplos é maior quando comparada a uma ovulação simples; devido a isto é necessário antecipar a retirada do dispositivo de progesterona do grupo superestimulado (BARUSELLI et al., 2006). Deste modo, a influência do eCG na expressão do sistema VEGF-A no útero bovino poderá ser comparada, já que todos os animais receberam tratamento padrão e foram abatidos no 6o dia após a ovulação. 


\section{Grupo controle $(n=3)$}

$B E(2 m g)+$

dispositivo de P4
PGF2 $\alpha$ + Remoção

do dispositivo de

P4

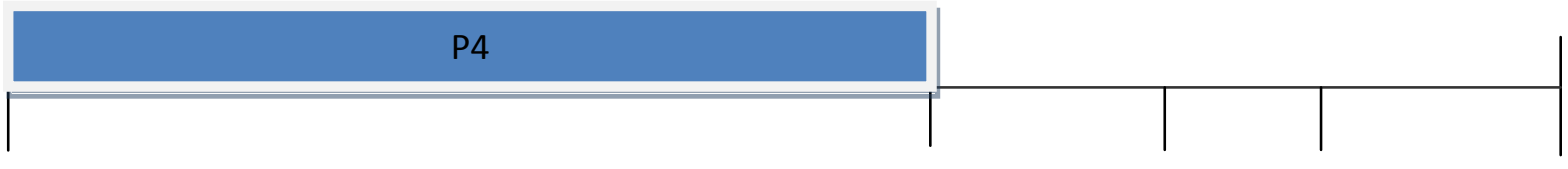

D0

D8

D10

D11

D17

Grupo de superestimulação folicular: Tratamento $1(n=3)$

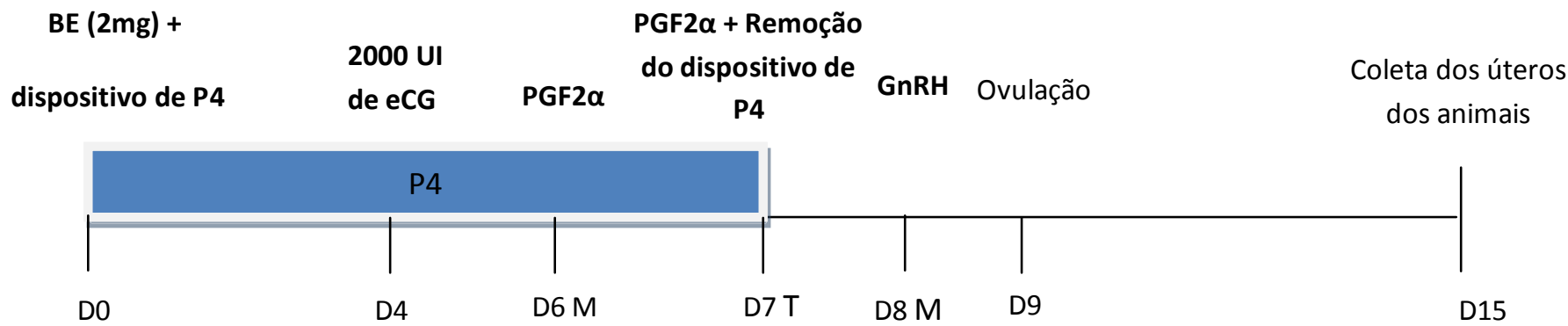

\section{Grupo de estimulação folicular: Tratamento $2(n=5)$}

$B E(2 \mathrm{mg})+$

dispositivo de P4
PGF2 $\alpha+$

400 Ul de eCG +

Remoção do dispositivo de P4
GnRH Ovulação

Coleta dos úteros

dos animais

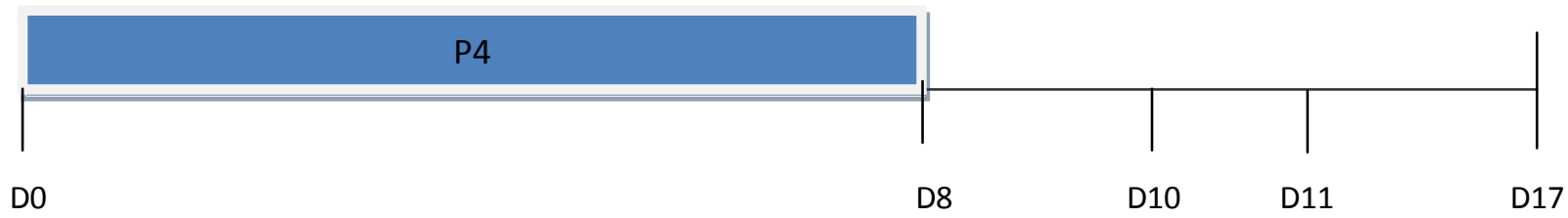

Figura 1. Modelo esquemático dos tratamentos utilizados nos animais controle, estimulado e superovulado. Legenda: $D=$ dia; T=tempo; $B E=$ benzoato de estradiol; PGF $2 \alpha=$ Prostaglandina $\mathrm{F} 2 \alpha$; $\mathrm{P} 4=$ progesterona; $\mathrm{n}=$ número de animais. 


\subsection{COLETA DE AMOSTRAS PARA IMUNOISTOQUÍMICA}

Após o abate dos animais e retirada do útero, as amostras do terço caudal de ambos os cornos uterinos foram coletadas. $O$ órgão foi seccionado em corte transversal, de forma a manter todas as camadas de tecido; em seguida, os fragmentos foram fixados em paraformaldeído a 4\%, durante 24 horas, lavados em solução tampão fosfato e submetidos ao processo de inclusão em parafina. Os fragmentos de tecido foram gradativamente desidratados em uma série de etanol com concentrações crescentes (70\%, 90\%, 100\%, 100\% e 100\%) por 1 hora cada, em seguida, foram diafanizados em uma série de xilol (I, II e III) por 1 hora cada e embebidos em parafina (I e II) por uma hora e em parafina III overnight.

Os blocos com tecido foram cortados em micrótomo (Leica, RM2125 RT), em 2,5 $\mu \mathrm{m}$ de espessura e dispostos em lâminas silanizadas (STAR FROST, Alemanha).

Os cortes foram desparafinizados em xilol ( $2 \times 10$ minutos), reidratados em uma série de etanol com concentrações decrescentes (100\%; 100\%; 90; 70 por 5 minutos cada) e lavadas em água destilada (5 minutos). Todas as lavagens seguintes foram realizadas com solução tamponada de fosfato (PBS 0,15 M; pH 7,2$7,4) 3 \times 5$ minutos. Posteriormente, as lâminas foram imersas em tampão citrato $\mathrm{e}$ receberam tratamento no micro-ondas ( $3 \times 5$ minutos em potência máxima) para melhor exposição dos antígenos. A atividade da peroxidase endógena foi bloqueada com Dual endogenous enzyme block (DAKO, S2003, Califórnia-USA) durante 10 minutos e em seguida lavadas em tampão fosfato. Para reduzir ligações inespecíficas, os cortes foram incubados por 10 minutos em solução de bloqueio Protein block serum-free (DAKO, X0909, Califórnia-USA). Os cortes foram incubados com os anticorpos primários (Quadro 1), diluídos em PBS, por 20 horas a $4^{\circ} \mathrm{C}$.

Depois da lavagem em PBS, os cortes foram incubados com o anticorpo secundário por 15 minutos e lavados novamente em PBS. Em seguida, incubaramse por 15 minutos com o complexo STREPTAVIDIN + HRP (DAKO, K0690, Califórnia-USA) para a amplificação do sinal da reação. A reação de 
imunoistoquímica específica foi revelada utilizando-se DAB + Substrate Cromogen System (DAKO, K3468, Califórnia, USA) por 60 segundos. Os cortes foram lavados em água destilada ( $2 \times 10 \mathrm{~min}$ ), contracorados com Hematoxilina de Harris por 15 segundos, lavados em água corrente por 8 minutos e, em seguida, montados com Permount $^{\Theta}$ (Fischer Scientific, 15969B, USA). Como controle negativo foram utilizados cortes que não receberam o anticorpo primário, apenas incubados com PBS. Como controles positivos foram utilizados cortes de placenta bovina, para os quais as mesmas reações haviam sido positivas em testes realizados em outros experimentos.

\begin{tabular}{|c|c|c|c|c|c|}
\hline Anticorpo & Clone/lsotipo & Hospedeiro & Diluição & $\begin{array}{c}\text { Seqüência de } \\
\text { peptídeos }\end{array}$ & $\begin{array}{c}\text { Fabricante } \\
\text { (número de } \\
\text { catálogo) }\end{array}$ \\
\hline $\begin{array}{c}\text { Anti -VEGF- } \\
\text { A }\end{array}$ & $\begin{array}{c}\text { A-20, policlonal, } \\
\operatorname{lgG}\end{array}$ & Coelho & $1: 200$ & $\begin{array}{c}\text { N-terminal do } \\
\text { VEGF-A } \\
\text { humano }\end{array}$ & $\begin{array}{c}\text { Santa Cruz } \\
\text { (sc-152) }\end{array}$ \\
\hline $\begin{array}{c}\text { Anti- } \\
\text { VEGFR1 }\end{array}$ & $\begin{array}{c}\text { C-17, policlonal, } \\
\operatorname{lgG}\end{array}$ & Coelho & $1: 400$ & $\begin{array}{c}\text { C-terminal do } \\
\text { VEGFR-1 } \\
\text { humano }\end{array}$ & $\begin{array}{c}\text { Santa Cruz } \\
\text { (sc-316) }\end{array}$ \\
\hline Anti- & $\begin{array}{c}\text { C-20, policlonal, } \\
\text { VEGFR2 }\end{array}$ & Coelho & $1: 400$ & $\begin{array}{c}\text { C-terminal do } \\
\text { VEGFR-2 } \\
\text { camundongo }\end{array}$ & $\begin{array}{c}\text { Santa Cruz } \\
\text { (sc-315) }\end{array}$ \\
\hline
\end{tabular}

Quadro 1 - Anticorpos primários utilizados na imunoistoquímica

\subsection{EXTRAÇÃO DO RNA}

A extração do RNA total foi realizada a partir do protocolo de Trizol ${ }^{\circledR}$. Cerca de $25 \mathrm{mg}$ de tecido foram pesados em gelo e acrescidos de $1000 \mu \mathrm{l}$ de Trizol e homogeneizados com o auxílio do aparelho homogenizador de tecidos (Polytron Ultra Turrax T-200, Oxford, USA). O homogenato foi armazenado a temperatura ambiente durante 5 minutos. Após este período, o material foi centrifugado por 10 minutos a $11.500 \mathrm{rpm}, 4^{\circ} \mathrm{C}$. 
Enquanto isso, novos tubos foram identificados e acrescidos de $500 \mu \mathrm{l}$ de isopropanol. Após a centrifugação, o sobrenadante foi transferido para os tubos contendo isopropanol, homogeneizados suavemente e incubados a temperatura ambiente por 3 minutos. As amostras passaram novamente por uma centrifugacão por 15 minutos, $11.500 \mathrm{rpm}$ a $4^{\circ} \mathrm{C}$. O sobrenadante foi descartado e o precipitado (RNA-Total) solubilizado com $1 \mathrm{ml}$ de álcool $75 \%$ diluído em água ultrapura autoclavada. Uma nova centrifugação foi realizada por 10 minutos, $9.000 \mathrm{rpm}$ a 4 ${ }^{\circ} \mathrm{C}$, o excesso de álcool foi retirado cuidadosamente e o precipitado (RNA Total) eluído em $20 \mu$ l de água ultrapura autoclavada.

\subsection{QUANTIFICAÇÃO DO RNA TOTAL}

Para a quantificação do RNA total, as amostras foram diluídas na proporção 1:50, ou seja, $49 \mu \mathrm{l}$ de $\mathrm{H}_{2} \mathrm{O}$ ultrapura autoclavada adicionados a $1 \mu \mathrm{l}$ do RNA total e homogeneizados suavemente.

A quantificação foi realizada no Biofotômetro (Eppendorf 22331, Hamburgo - Germany) a 260/280 nm. A fim de evitar que uma eventual contaminação por DNA genômico interferisse nos resultados, todas as amostras de RNA total foram tratadas com DNase antes de serem submetidas ao RT-PCR. Conforme as instruções do protocolo DNase I - Amplification Grade (Invitrogen $\circledast$, Carlsband, USA), o volume da solução de RNA total a ser tratado com DNase foi calculado a fim de conter $1 \mu \mathrm{g}$ de RNA total. A este volume, foi adicionado $1 \mu \mathrm{l}$ de tampão DNAse, $1 \mu \mathrm{l}$ de DNAse I (unidade/ul) e água "RNAse free" (água ultrapura autoclavada) suficiente para completar $10 \mu \mathrm{l}$. Essa solução permaneceu a temperatura ambiente durante 15 minutos e, em seguida, foi acrescida de $1 \mu \mathrm{l}$ de EDTA ( $25 \mathrm{mM}$ ) e incubada por 15 minutos. Após esse procedimento, as amostras foram transferidas para o gelo e imediatamente submetidas à reação de transcrição reversa. 


\subsection{CONFECÇÃO DO cDNAS}

Para a reação de transcrição reversa (RT), foi utilizado o "Kit SuperScript III (Invitrogen ${ }^{\circledR}$, Carlsband, USA) cujo protocolo iniciou-se com a utilização de $1 \mu \mathrm{g}$ do RNA total, acrescido de $1 \mu$ INase (Invitrogen ${ }^{\circledR}$ ), $10 \mu$ lde tampão, incubados por 15 minutos a temperatura ambiente e depois foi adicionado $1 \mu \mathrm{l}$ de EDTA para incubação a $65^{\circ} \mathrm{C}$ por 10 minutos. A seguir, adicionou-se $1 \mu \mathrm{l}$ de oligonucleotídeos iniciadores Oligo (dt) $(500 \mu \mathrm{g} / \mathrm{ml})$ e $1 \mu \mathrm{l}$ de dNTP Mix (10nM). Essa solução foi incubada a $65^{\circ} \mathrm{C}$ por 5 minutos. Após essas etapas, foram adicionados à solução 5 $\mu \mathrm{l}$ de tampão, $1 \mu \mathrm{l}$ de água ultrapura autoclavada, $1 \mu \mathrm{l}$ de DTT $(0,1 \mathrm{M})$ e $1 \mu \mathrm{l}$ de

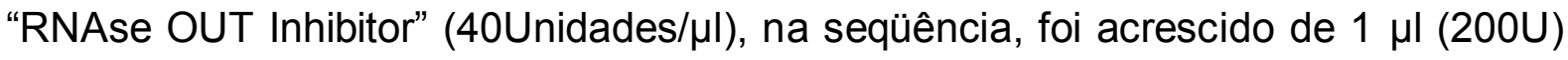
de SuperScript III (transcriptase reversa) e iniciou-se a incubação, primeiramente a $37^{\circ} \mathrm{C}$ por 50 minutos, depois a $70^{\circ} \mathrm{C}$ por 15 minutos e finalmente a $4^{\circ} \mathrm{C}$ por 2 minutos. $\mathrm{O}$ cDNA foi armazenado a $-20^{\circ} \mathrm{C}$ até o momento da amplificação dos genes alvo e controle endógeno pela técnica de PCR em tempo real.

\subsection{PCR EM TEMPO REAL}

Após a transcrição reversa (RT), foi realizado o PCR em Tempo Real (Real Time PCR) no aparelho ABIPrism ${ }^{\circledR} 7500$ (Applied Biosystems, Foster, USA). Neste sistema, as fases de anelamento, extensão e desnaturação ocorrem de maneira similar quando da utilização do termociclador comum, uma vez que o ABIPrism 7500 é um termociclador acoplado a uma câmera CCD. A diferença é que a amplificação da seqüência alvo é detectada em tempo real pela emissão de fluorescência, que ocorre quando há formação de dupla fita na região codificada pelo par de primers. A quantificação relativa da amplificação é feita pela fluorescência captada pela unidade óptica do aparelho. A amplificação é detectada onde as condições "ótimas" para o PCR são mantidas, ou seja, na fase exponencial. 
Como controle interno das reacões de PCR em tempo real foi utilizado a amplificacão do gene costitutivamente expresso tubulina, a fim de normalizar os resultados obtidos para os genes-alvo. Os primers para os genes em estudo e o controle endógeno foram obtidos a partir de seqüências bovinas previamente publicadas. As reações foram realizadas utilizando o sistema TaqMan ${ }^{\circledR}$ (Applied Biosystems, Foster, USA). Os PCRs foram conduzidos em duplicatas para cada amostra e a expressão determinada pela quantificação em relação ao gene controle. Foi preparada uma mistura (Mix) para cada gene estudado. Neste mix foram adicionados, por amostra a ser analisada, 6,25 $\mu \mathrm{l}$ de tampão Universal PCR Master Mix (Applied Biosystems, Foster, USA), 0,5 $\mu$ ld primers sense e antisense (concentração final de $900 \mathrm{mM}$, quadro 2), sonda (concentração final de $250 \mathrm{mM}$ ) para os genes alvo e 2,5 $\mu \mathrm{l}$ de cDNA e a quantidade de água ultrapura autoclavada necessária para completar um volume final de $12,5 \mu \mathrm{l}$.

O cálculo da eficiência para os genes alvo e controle foram feitas através do programa "LinRegPCR" (RAMAKERS et al., 2003). Para isso, considera-se a eficiência média com base na curva de amplificação individual de cada amostra. $O$ cálculo da quantificação relativa dos genes-alvo foi feito através da fórmula de Pfaffl (PFAFFL, 2001):

$\mathbf{R}=\left(\mathrm{E}_{\text {target }}\right)^{\Delta \mathrm{CP}}$ target (calibrador -amostra) $/\left(\mathrm{E}_{\text {ref }}\right)_{\text {ref }}^{\Delta \mathrm{CP}}$ (calibrador - amostra)

$$
\begin{aligned}
& R \text { (ratio) = expressão relativa do gene alvo } \\
& E_{\text {target }}=\text { eficiência de amplificação do gene alvo } \\
& E_{\text {ref }}=\text { eficiência de amplificacao do gene de referência (GAPDH) } \\
& \Delta \mathrm{CP}_{\text {target }}=\text { CP do gene alvo }-\mathrm{CP} \text { do gene de referência } \\
& \Delta \mathrm{CP}_{\text {ref }}=\mathrm{CP} \text { do gene alvo }-\mathrm{CP} \text { do gene de referência }
\end{aligned}
$$




\begin{tabular}{|c|c|c|c|c|}
\hline Gene alvo & $\begin{array}{c}\text { Número da } \\
\text { seqüencia } \\
\text { no GeneBank }\end{array}$ & Primers & Sondas & $\begin{array}{l}\text { Tamanho do } \\
\text { amplicom }\end{array}$ \\
\hline VEGF & NM_174216 & $\begin{array}{l}\text { S GCC CAC TGA GGA } \\
\text { GTT CAA CAT } \\
\text { A CTG GTC TTG GTG } \\
\text { AGG TTT GAT C }\end{array}$ & $\begin{array}{l}\text { CACCATGCAGATTATGM } \\
\text { GBNFQ }\end{array}$ & 60 \\
\hline Flt-1 & X94263 & $\begin{array}{l}\text { S GCC TGA AAT CTA } \\
\text { CCA GAT CAT GTT G } \\
\text { A TTC CAC AAG CTC } \\
\text { CAC GAA TCT T }\end{array}$ & $\begin{array}{l}\text { ACAAAGACCCAAAAGAA } \\
\text { AGMGBNFQ }\end{array}$ & 58 \\
\hline KDR & X94298 & $\begin{array}{l}\text { S ACT GCA GTG ATG } \\
\text { GCG TCT T } \\
\text { A CTT GTA GGC TCC } \\
\text { AGT ATC ATT TCC A }\end{array}$ & $\begin{array}{l}\text { CTGTAAGATGCTCACAA } \\
\text { TTTMGBNFQ }\end{array}$ & 64 \\
\hline Tubulina & AC_000169.1 & $\begin{array}{l}\text { S TGT TCG CTC AGG } \\
\text { TCC TTT TGG } \\
\text { A CCC TTG GCC CAG } \\
\text { TTG TTG }\end{array}$ & $x^{2}$ & 79 \\
\hline
\end{tabular}

Quadro 2. Seqüência dos oligonucleotídeos iniciadores e sondas utilizadas para a amplificação do VEGF, Flt-1, KDR e tubulina, $S=$ sense e $A$ = anti-sense. 


\subsection{ESTIMATIVA DA DENSIDADE DO NÚMERO DE GLÂNDULAS UTERINAS}

As mensurações estereológicas para estimativa da densidade das glândulas no endométrio uterino foram realizadas utilizando-se o princípio do método de contagem de pontos (Point counting test) de acordo com as recomendações descritas em Gundersen et al. (1988).

Primeiramente, três (03) lâminas de cada animal, contendo um corte cada, foram selecionadas aleatoriamente. Após a coloração de Hematoxilina Eosina, visualizou-se através de microscópio óptico e objetiva de 10x, a margem superior esquerda do corte e a partir dessa margem, foram tiradas fotografias dos campos de visão, com uma distância de $1 \mathrm{~mm}$ entre eles, de forma que todo o corte fosse fotografado (Figura 2). Tal distância foi determinada através dos eixos $\mathrm{x}$ e y do microscópio. As imagens foram captadas por câmera digital, acoplada ao microscópio Olympus, BX-60 (Center Valley, USA) e à câmera Axiocam HRc (Zeiss, Alemanha) por meio do programa Axio vison 4.8 Lymous (Zeiss, Alemanha) e enviadas a um computador em arquivos formato "jpeg" e resolução de 3900 x 3090 pixels para análise.

Frames de contagem de área conhecida $\left(A_{[\text {fra] }}\right.$; largura * altura $)$ foram sobrepostos às imagens e as glândulas uterinas do endométrio, contidas no interior do frame e que não estivessem interceptadas pelas linhas de exclusão, foram tabuladas (figura 3). A área do corte $\left(A_{A}\right)$, na qual as glândulas uterinas foram quantificadas, foi estimada multiplicando-se a área do frame $\left(A_{[\text {fra] }}\right)$ pelo número de frames utilizados $\left(\mathrm{N}_{[\text {[ra] }}\right)$, divididos pela magnificação linear da imagem (100x) ao quadrado $\left(M^{2}\right)$, enquanto a densidade de glândulas existente por corte $\left(N_{A}\right)$ foi calculada dividindo-se o somatório das glândulas quantificadas $(\Sigma Q)$ pela respectiva área do corte $\left(A_{A}\right)$. Já o número total de glândulas $(N)$ existentes por corte foi estimado multiplicando-se a densidade numérica $\left(N_{A}\right)$ pela área $\left(A_{r e f}\right)$ da respectiva região, a qual foi previamente mensurada através de ultrassom. 


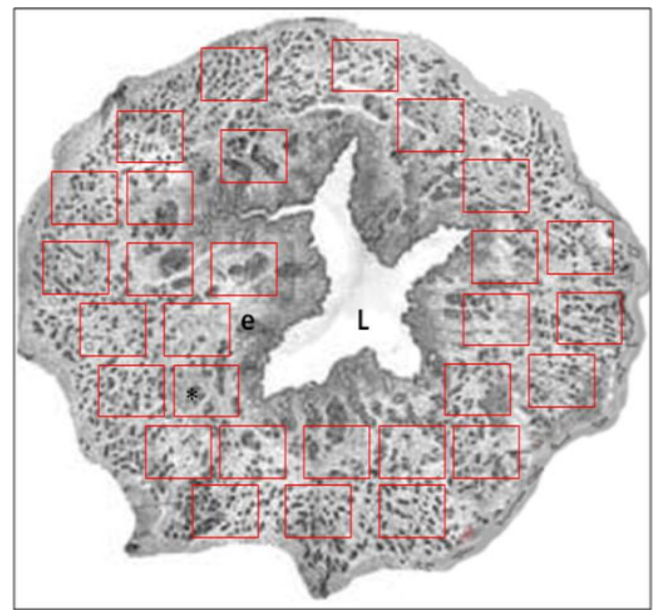

Figura 2 - Esquema do útero bovino. Metodologia utilizada para seleção dos campos de contagem das glândulas (figura adaptada de Wang et al., 2007). Os quadrados vermelhos representam os campos que foram utilizados para contagem. Abreviaturas: $L=$ lume; $e=$ endométrio.

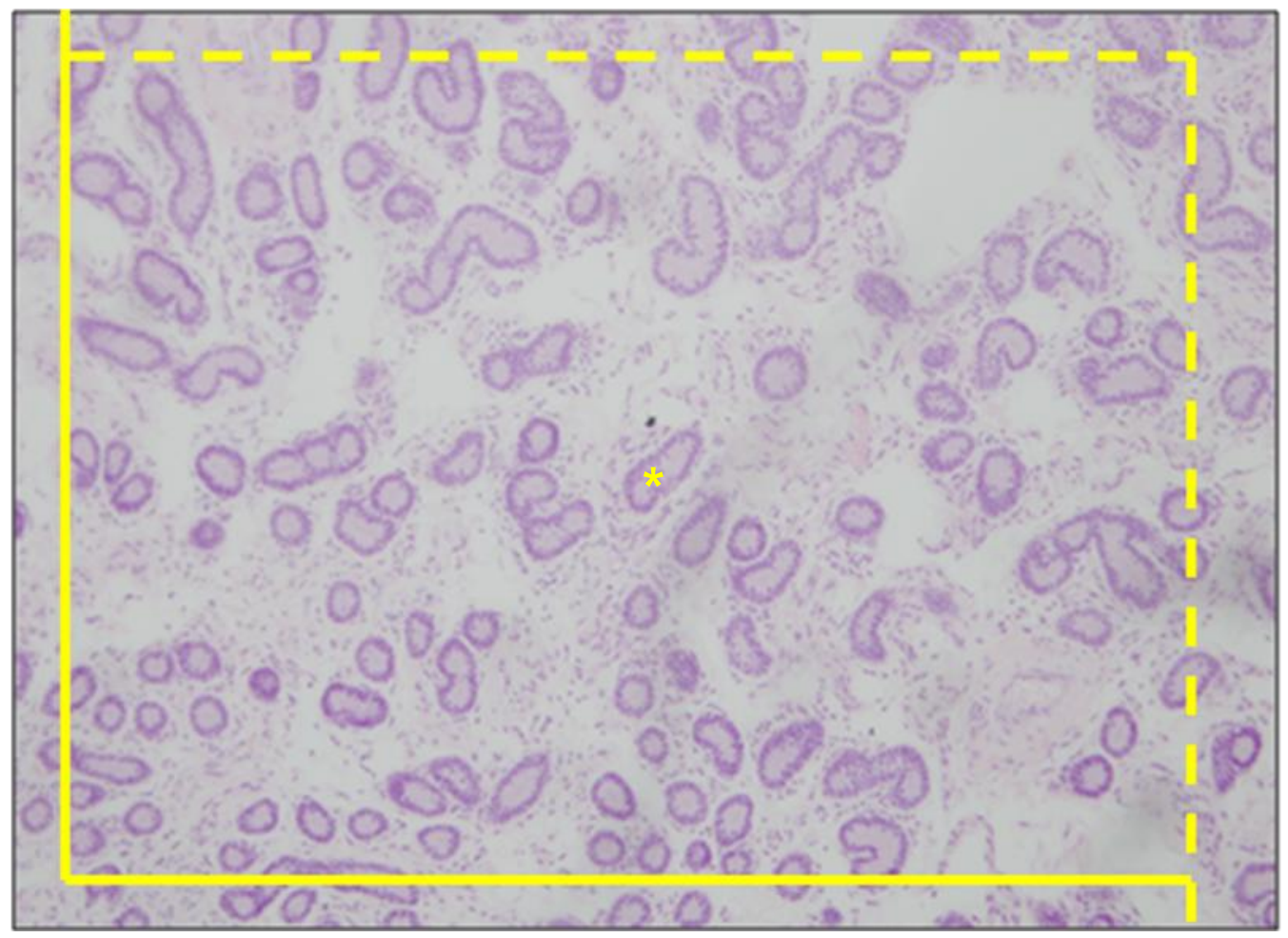

Figura 3 - Fotomicrografia do endométrio bovino, com um frame sobreposto para estimar o número de glândulas uterinas (*). Consideram-se as glândulas contidas no interior do frame e que não estejam interceptadas pelas linhas de exclusão (linhas cheias). 


\subsection{ANÁLISE ESTATÍSTICA}

Primeiramente, a distribuição dos dados foi avaliada com um teste de Normalidade. Quando os dados apresentaram distribuição não normal, foi utilizado o teste Kruskal-Wallis seguido do teste de comparações múltiplas de Dunn. Por outro lado, quando os dados apresentaram distribuição normal, aplicou-se o teste ANOVA seguido pelo teste de comparação múltipla de Tukey (GraphPad Software Inc., San Diego, CA, USA). Foi realizado também o teste de correlação de Pearson, quando os dados obtidos apresentaram distribuição normal, e o teste de correlação de Spearman, quando eles apresentaram distribuição não normal. Os resultados foram apresentados por média \pm EPM e o nível de significância adotado foi $p<0,05$. 


\section{RESULTADOS}

Inicialmente, estão demonstrados os resultados relativos à imunolocalização do sistema VEGF nos grupos controle, estimulado e superovulado. Em seguida, são descritas as análises de expressão gênica do sistema VEGF-A dos grupos controle, estimulado e superovulado. Por fim, são demonstrados os valores estimados da densidade das glândulas uterinas presentes nos diferentes grupos, os valores médios da P4 plasmática nos diferentes grupos e a correlação realizada entre os valores da expressão gênica do sistema VEGF-A e os valores estimados da densidade glandular com a P4 total dos animais.

\subsection{IMUNOLOCALIZAÇÃO DO SISTEMA VEGF NO ÚTERO DE BOVINOS}

Através da imunoistoquímica, o sistema VEGF-A foi detectado no útero bovino em diferentes compartimentos e em todos os grupos estudados: controle, estimulado e superovulado.

O sinal positivo das proteínas do VEGF-A e de seus receptores, Flt-1 e KDR, foi observado no citoplasma das células dos epitélios uterino e glandular, bem como no citoplasma das células endoteliais dos vasos sanguíneos (Figuras 4, 5 e 6).

Visualmente, a intensidade da marcação tanto do VEGF-A quanto do KDR não variou entre os grupos experimentais (Figuras 4 e 6). Entretanto, ao analisarmos o Flt-1, verificamos que o seu sinal foi mais intenso no citoplasma das células dos epitélios uterino e glandular nos grupos superovulado e estimulado em relação ao grupo controle (Figura 5). 

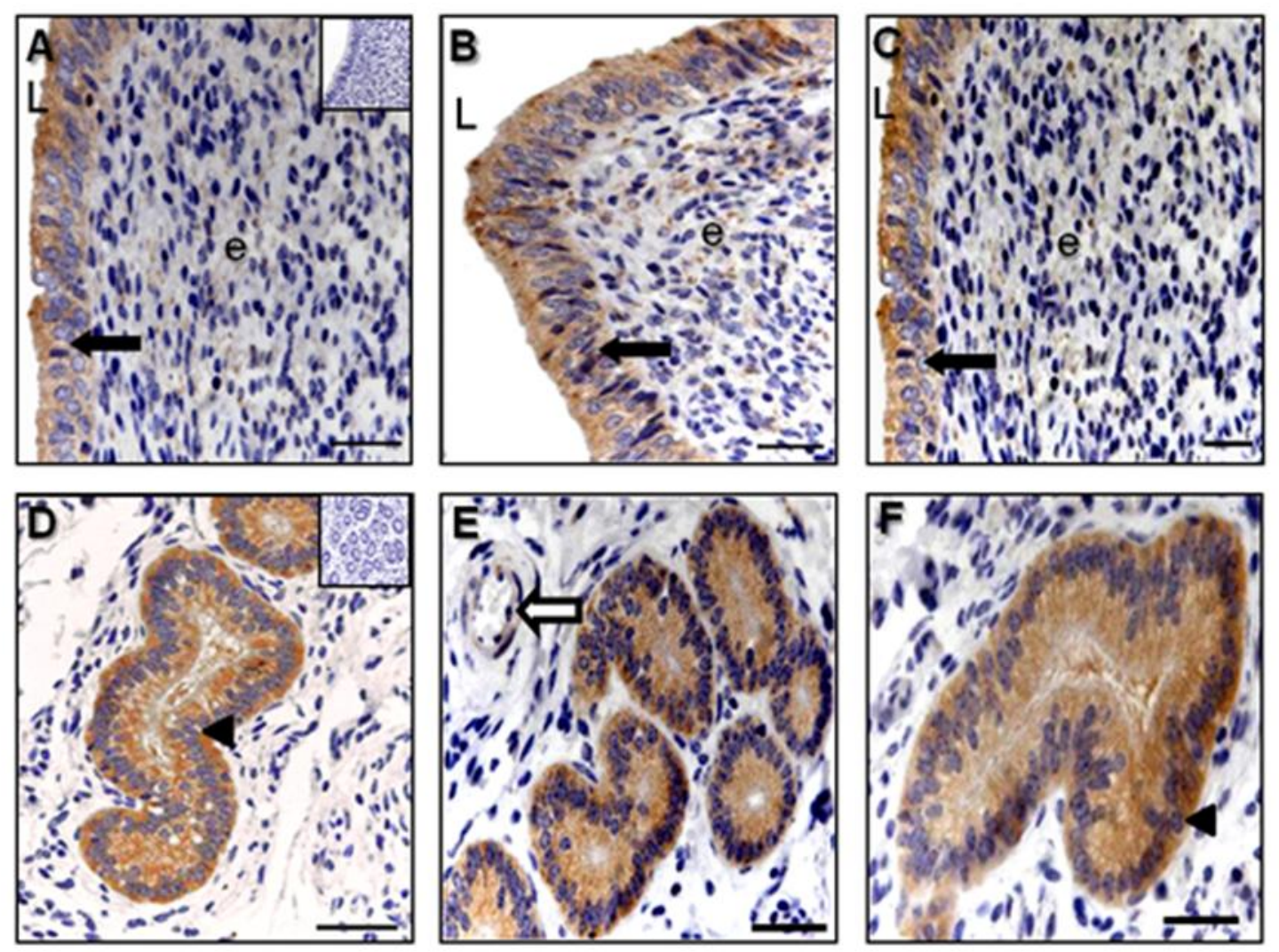

Figura 4 - Expressão do VEGF-A no útero bovino após o tratamento com dif erentes doses de eCG ( $A, B, C)$. Expressão da proteína VEGFA no epitélio uterino (seta cheia) dos grupos controle (A), estimulado (B) e superovulado (C). (D, E, F) - Expressão da proteína VEGF-A nas glândulas uterinas (cabeça de seta) dos grupos controle (D), estimulado (E) e superovulado (F). Presença de vasos sanguíneos em $E$ (seta vazia). Abreviaçôes: $e=$ estroma uterino. L= lume. Inserts em A e D controle negativo. Barra: 50um 

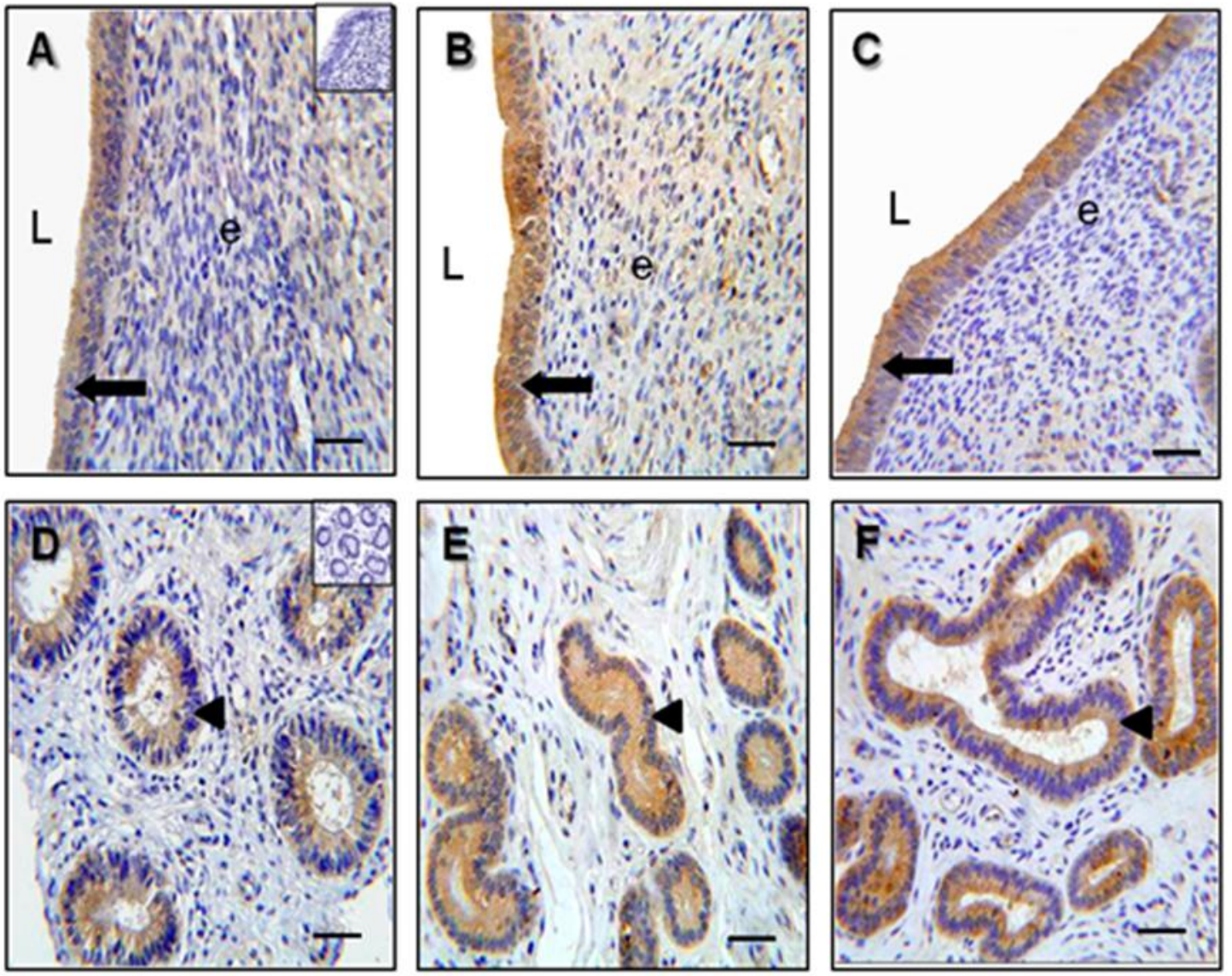

Figura 5 - Expressão do Flt-1 no epitélio uterino e glandular nos grupos controle (A), estimulado (B) e superovulado (C). (D, E, F) Glândulas uterinas (cabeça de seta) com a expressão do Flt-1 nos grupos controle (D), estimulado (E) e superovulado (F). Abraviações: $e=$ estroma uterino. $L=$ lume. Inserts em $A$ e $D=$ controle negativo. Barra 50 um 

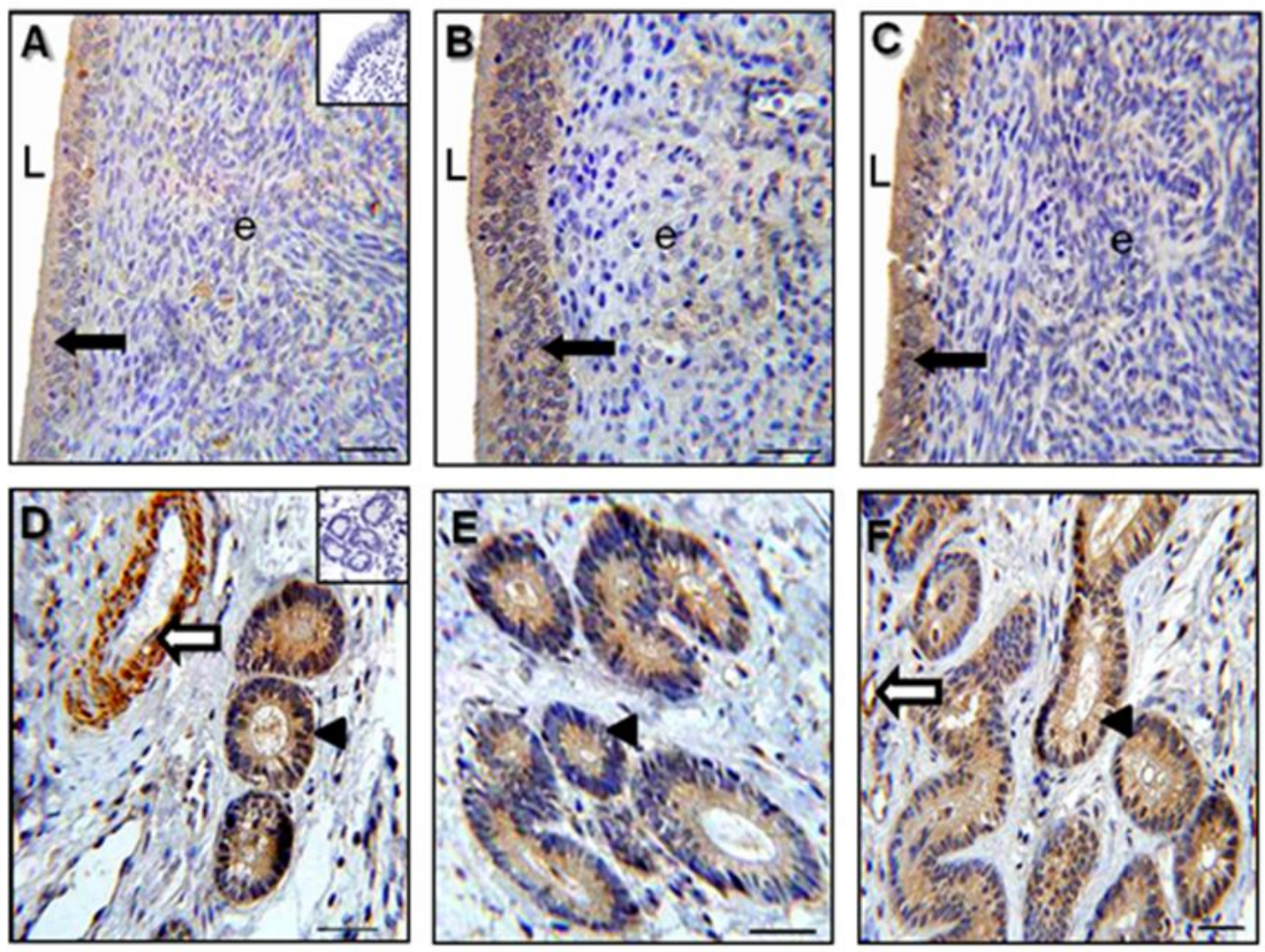

Figura 6 - Expressẫo do KDR no epitélio uterino (seta cheia) e nas glândulas uterinas (cabeça de seta) nos grupos controle (A), estimulado (B) e superovulado (C). Expressão KDR nas glândulas uterinas (cabeça de seta) e nos vasos sanguíneos (seta vazia) nos grupos controle (D), estimulado (E) e superovulado (F). Abreviações: e= estroma uterino. L= lume. Inserts em A e D = controle negativo. Barrra $=50$ um. 


\subsection{EXPRESSÃO GÊNICA DO SISTEMA VEGF-A NO ENDOMÉTRIO BOVINO}

Não foram observadas diferenças significativas na expressão gênica do sistema VEGF-A nos cornos uterinos dos animais dos grupos estimulado e superovulado, em relação ao grupo controle $(P>0,005)$.

$\mathrm{Na}$ figura 7 , são apresentados os valores de expressão gênica dos cornos ipsolateral e contralateral ao $\mathrm{CL}$, dos animais controle (figura 7A) e estimulado (figura 7B). Os dados foram apresentados por corno uterino, para evidenciar que os valores não demonstram diferenças significativas entre si.

$\mathrm{Na}$ figura 8, são apresentados os valores da expressão gênica do sistema VEGF-A nos três grupos estudados. Podemos observar que não ocorreram diferenças de expressão do sistema VEGF-A entre esses grupos, o que pode ser evidenciado pelos valores da expressão do VEGF (figura 8A), Flt-1 (figura 8B) e do KDR (figura 8C). 
A

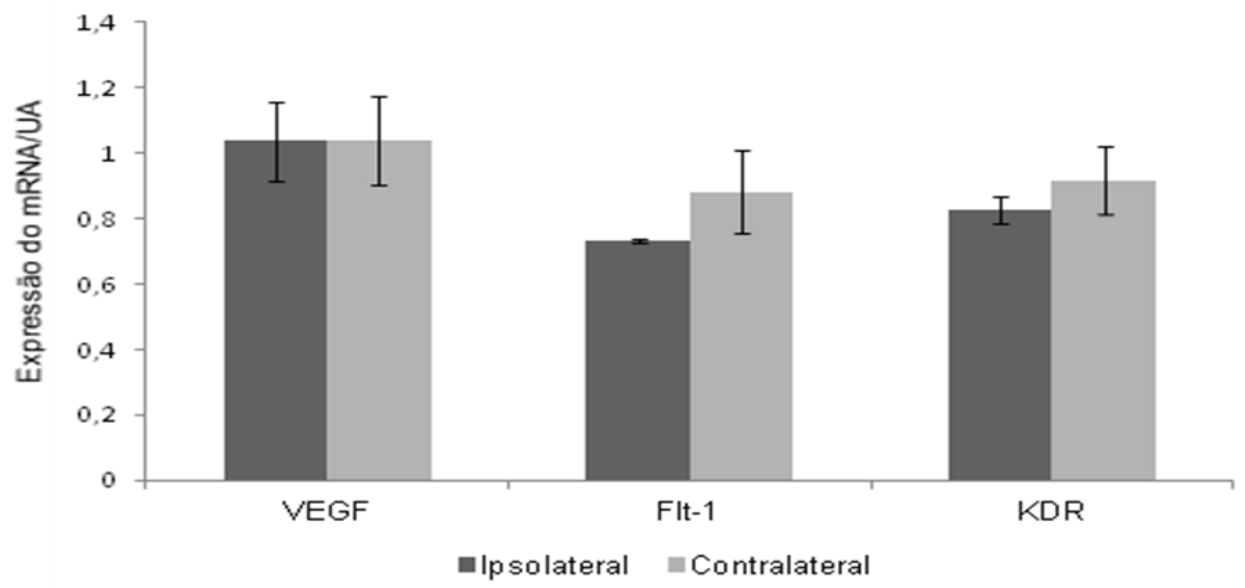

B

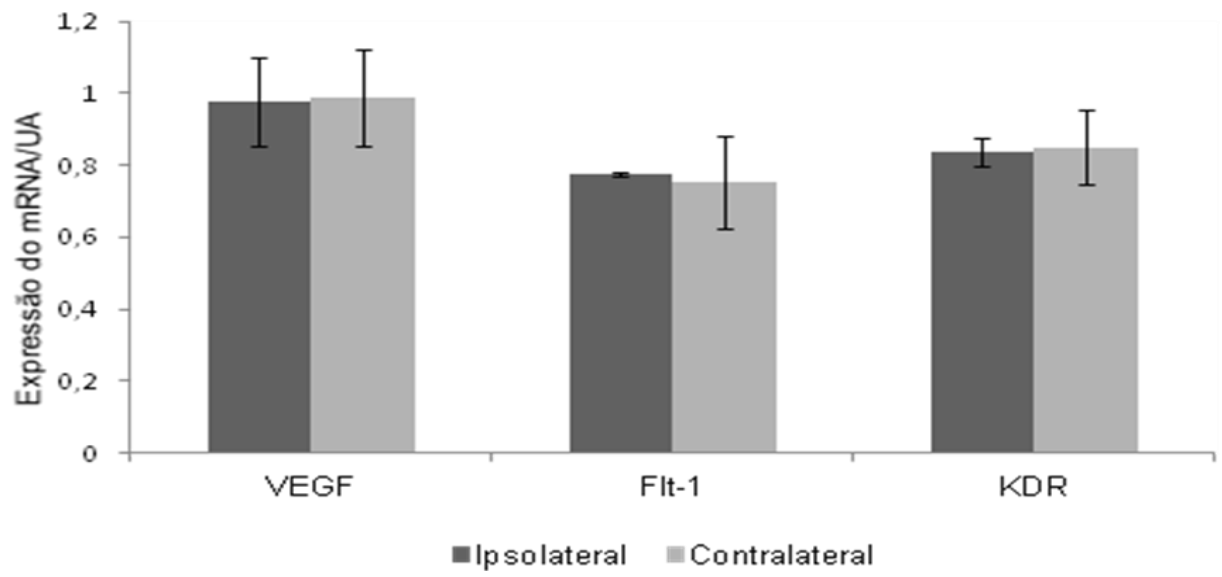

Figura 7 - A expressão do mRNA do Sistema VEGF-A nos cornos uterinos ipsolateral e contralateral dos animais dos grupos controle (A), estimulado (B). Não foi observada diferença significativa $(P>0,05)$. Os dados estão expressos em média e \pm EPM. 
A

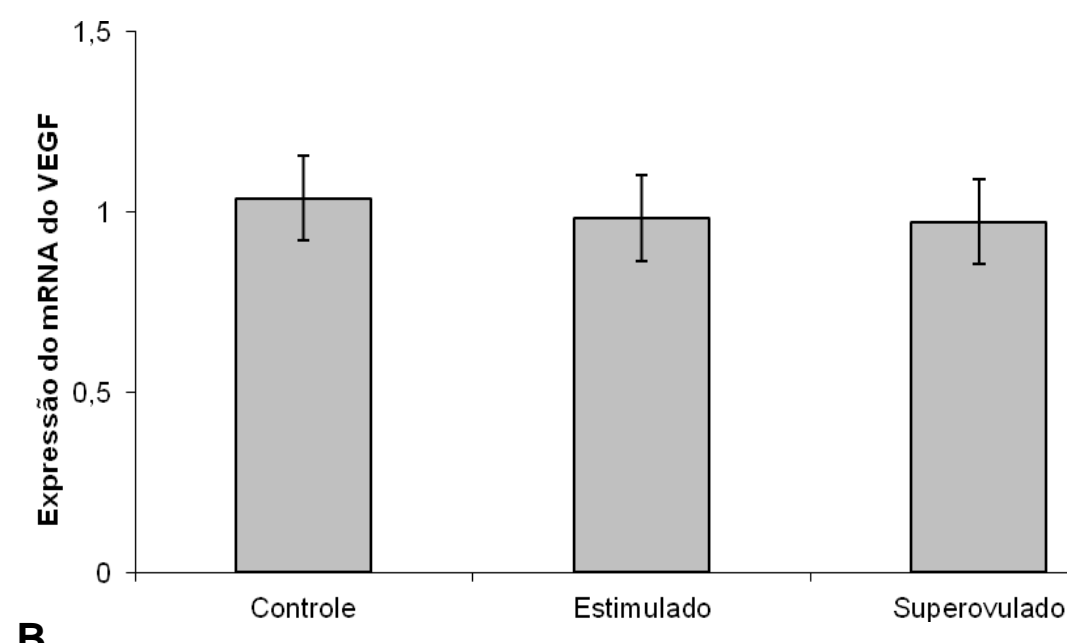

B

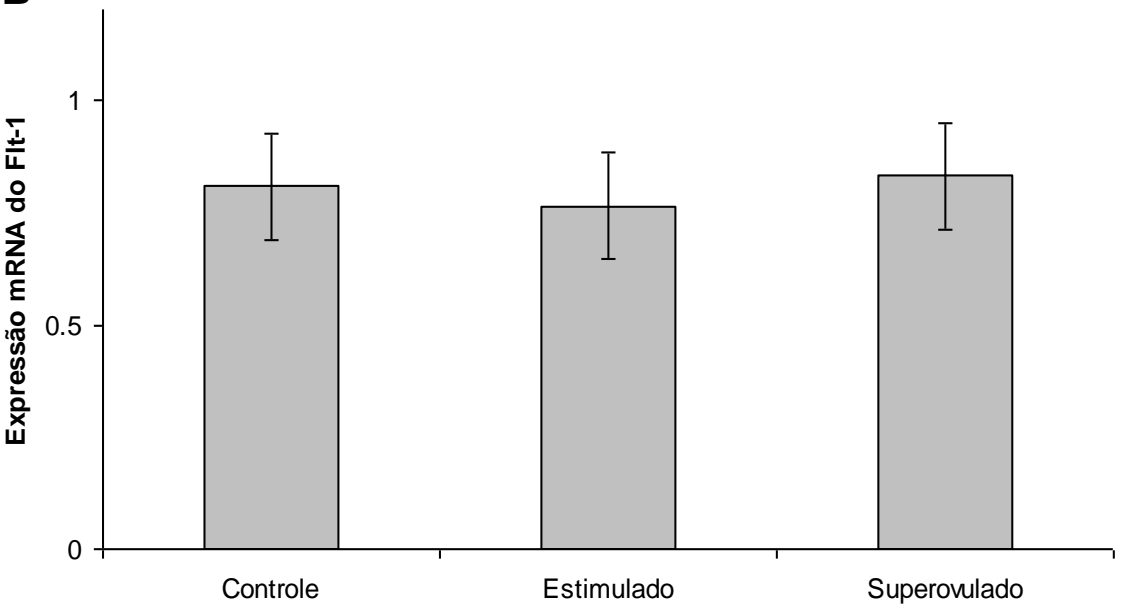

C

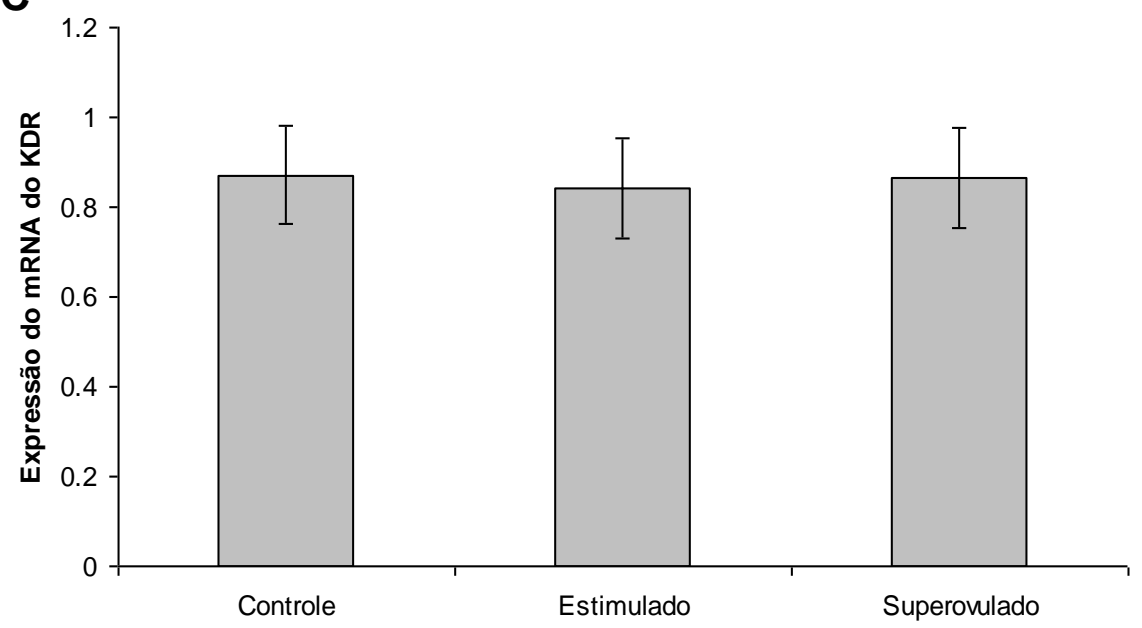

Figura 8 - Expressão do RNAm VEGF-A (A), Flt-1 (B) e KDR (C) no endométrio dos animais grupos controle, estimulado e superovulado. Não foi observado diferença significativa $(P>0,05)$. Os dados estão expressos em média e $\pm E P M$. 


\subsection{ESTIMATIVA DA DENSIDADE DO NÚMERO DE GLÂNDULAS UTERINAS}

Foi analisada a densidade glandular por corte (número de glândulas por $\mathrm{mm}^{2)}$ como também a estimativa do numero total de glândulas por corte. Tanto a densidade glandular como o número total de glândulas (figura 9) foram maiores no grupo superovulado em relação aos grupos controle e estimulado $(p<0.0001)$.

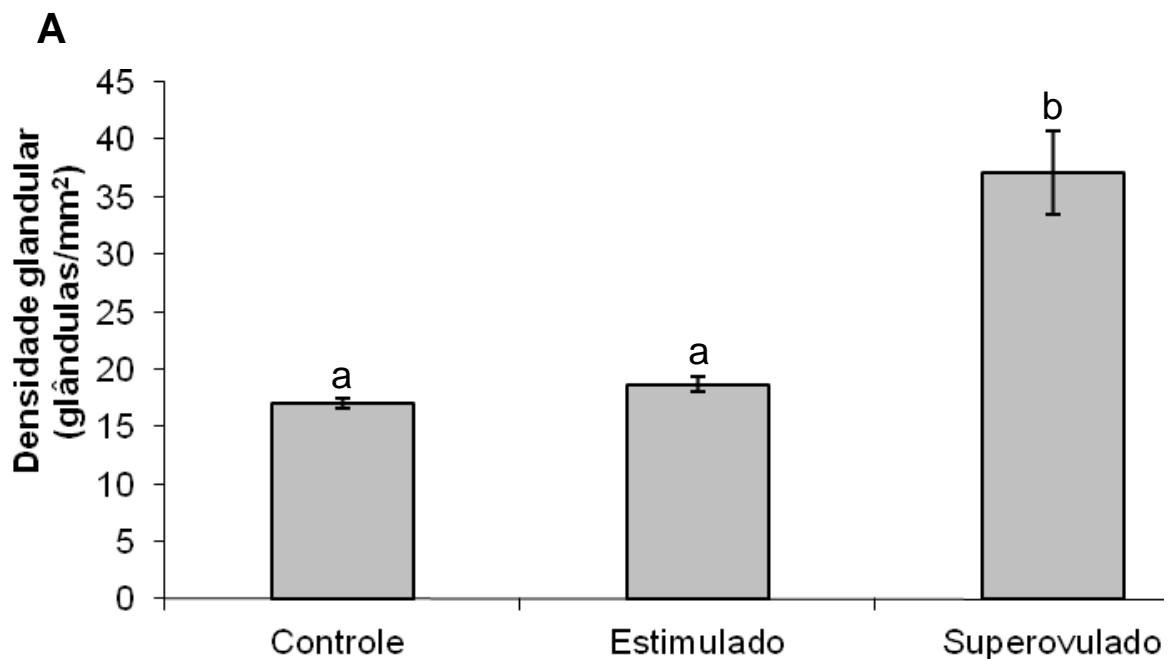

B

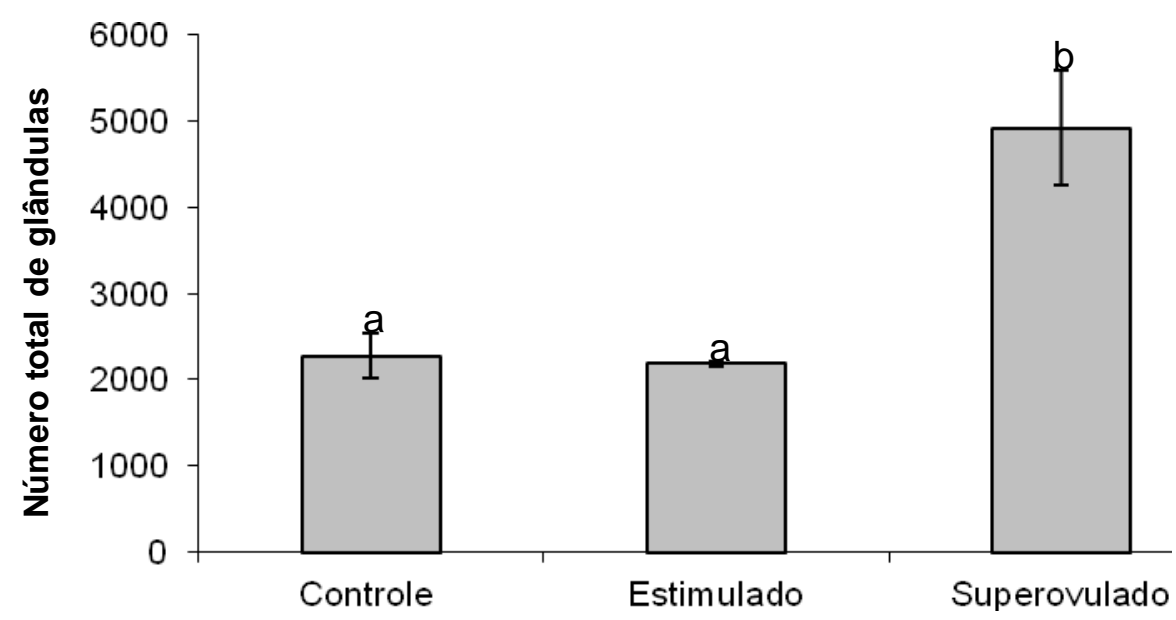

Figura 9 - Densidade glandular (número de glândulas por $\mathrm{mm}^{2}$; A) e número total de glândulas uterinas (B) nos animais dos grupos controle, estimulado e superovulado. Os resultados estão expressos em média e +/-EPM. Letras diferentes apresentaram diferença significativa $(\mathrm{P}<0,0001)$. 


\section{4 - CONCENTRAÇÃO DA PROGESTERONA PLASMÁTICA}

A concentração de progesterona plasmática total foi maior no grupo estimulado quando comparado ao grupo controle, bem como no grupo superovulado, quando comparado ao grupo controle e estimulado $(p<0,05$; tabela 1).

Tabela 1 - Valores de Concentração de progesterona plasmática total nos animais dos grupos controle $(n=5)$, estimulado $(n=6)$ e superovulado $(n=7)$. (a) média dos valores de progesterona de todos os animais do grupo; (b) desvio padrão da média.

\begin{tabular}{|c|c|}
\hline \multicolumn{2}{|c|}{$\begin{array}{l}\text { Progesterona Plasmática total } \\
\qquad(\mathrm{ng} / \mathrm{ml})\end{array}$} \\
\hline Controle & $3.69^{\mathrm{a}}(1.78)^{\mathrm{b}}$ \\
\hline Estimulado & $5.94^{\mathrm{a}}(1.24)^{\mathrm{b}}$ \\
\hline Superovulado & $85,12^{a}(62,55)^{b}$ \\
\hline
\end{tabular}


5.5 ANÁLISE DE CORRELAÇÃO DA PROGESTERONA PLASMÁTICA COM OS DIFERENTES PARÂMETROS AVALIADOS

Quando analisamos a expressão gênica do sistema VEGF-A em relação à P4 plasmática e ao número de glândulas uterinas nos grupos estudados, observamos a existência de uma correlação positiva entre o Flt-1 e o KDR ( $r=0,60 p=0,0045)$ e entre a concentração plasmática de $\mathrm{P} 4$ e a densidade de glândulas uterinas $(r=0,74$ $\mathrm{p}=0,0078)$ (Tabela 2$)$.

Tabela 2 - Correlação entre a expressão gênica do sistema VEGF, a P4 plasmática e o número de glândulas uterinas.

\begin{tabular}{c|c|c}
\hline Correlação & $\mathbf{r}$ & $\mathbf{P}$ \\
\hline VEGF x Flt-1 & 0,22 & 0,34 \\
VEGF x KDR & 0,32 & 0,15 \\
$\begin{array}{c}\text { VEGF x } \\
\text { Glândulas }\end{array}$ & $-0,14$ & 0,62 \\
VEGF x P4 & 0,32 & 0,89 \\
Flt-1 x KDR & 0,60 & 0,0045 \\
$\begin{array}{c}\text { Flt-1 x } \\
\text { Glândulas }\end{array}$ & 0,12 & 0,66 \\
Flt-1 x P4 & 0,11 & 0,70 \\
KDR x & $-0,16$ & 0,56 \\
Glândulas \\
KDR x P4 & $-0,1$ & 0,71 \\
Glândulas x P4 & 0.74 & 0,0078 \\
\hline
\end{tabular}




\section{DISCUSSÃO}

Estudar os efeitos de tratamentos com eCG nas características morfofuncionais do endométrio é importante uma vez que estes tratamentos aumentam as taxas de concepção (BARUSELLI et al., 2003). Deste modo, estudamos a densidade das glândulas uterinas e a expressão de fatores de crescimento relacionados à vascularização na tentativa de melhor compreender como as gonadotrofinas influenciam o ambiente uterino.

Estudos morfométricos têm sido utilizados com sucesso para monitorar alterações patológicas no endométrio bovino (GONZALEZ et al., 1985) e para estudar os efeitos de drogas e hormônios no endométrio humano (JOHANNISSON, 1991). A partir de avanços recentes nos estudos morfométricos, foi possível a identificação de mudanças cíclicas e morfológicas no endométrio que ocorrem na fase folicular e luteínica no útero de humanos e ruminantes (WAHAB et al., 1999; DHALIWAL et al., 2002). A partir destes métodos, Wang et al (2007) descrevem que é possível analisar mudanças diretas nas glândulas uterinas com o método de contagem. Além disso, Johannisson et al (1987) correlacionou os níveis de 17ßestradiol e P4 com o diâmetro glandular do endométrio humano durante as fases proliferativa e secretória. Dessa maneira, no nosso estudo, também foi aplicado um método de contagem para avaliar a densidade glandular, o número total de glândulas e foram feitas as correlações com a concentração total de P4 circulante.

Durante o ciclo estral, os padrões de mudança na morfologia uterina refletem as variações do estradiol e P4 (JOHNSON; REDMER; REYNOLDS, 1997). Dados ainda não publicados do nosso grupo mostraram que os níveis de P4 por CL nos animais do grupo estimulado foram maiores. Entretanto, a P4 total foi maior nos animais do grupo superovulado. A preparação do útero para a implantação do embrião em todos os animais, incluindo os ruminantes, envolve alterações espaçotemporais nos perfis de expressão gênica que são cuidadosamente orquestradas (LONERGAN et al., 2011). Apesar da importância da P4 para o início e manutenção da gestação em mamíferos, paradoxalmente, o epitélio endometrial cessa a expressão de receptores de P4 antes da implantação, apesar da mesma ser 
mantida no estroma e miométrio. A perda de receptores de P4 no epitélio uterino parece ser um pré-requisito para o reconhecimento materno da gestação e o desenvolvimento do concepto em fases iniciais (BAZER et al., 2009).

Além disso, concentrações elevadas de P4 induzem o início da regulação negativa dos receptores de P4 (OKUMU et al., 2010) e está associada com um avanço nas mudanças temporais normais que ocorrem no transcriptoma endometrial (FORDE et al., 2010). A importância do histotrófo para o desenvolvimento do concepto foi demonstrado em um modelo de knockout de glândula uterina em ovelhas em que os embriões não se desenvolvem além do estágio de blastocisto (GRAY et al., 2001).

Um dos efeitos do tratamento com eCG é o aumento da P4 na circulação sanguínea. Esse aumento tem um papel fundamental no estabelecimento e manutenção da prenhez. O útero é o órgão alvo de atuação da P4, que age através dos receptores de progesterona expressos no epitélio e estroma endometrial, durante o inicio da fase luteínica (SPENCER; BAZER, 2004). Para o inicio e manutenção da gestação é necessário que ocorram interações no ambiente uterino que são dependentes de hormônios esteróides (SPENCER; BAZER et al., 2004), causando um processo de hiperplasia seguido de hipertrofia, nas glândulas endometriais dos animais domésticos, o que possibilita que o endométrio aumente a secreção de proteínas. Desta maneira, no presente estudo foi encontrado, além de um maior número de glândulas por $\mathrm{mm}^{2}$, uma maior estimativa de quantidade total de glândulas na área do endométrio nos animais do grupo superovulado, sugerindo que a concentração elevada de P4 total destes animais aumente o desenvolvimento das glândulas uterinas, o que corrobora com DHALIWAL et al (2002) e WANG et al (2007), que descreveram um aumento do número glândulas uterinas durante a fase luteínica, em que os níveis de P4 são maiores.

Wang et al (2007) correlacionam positivamente altos níveis de P4 com os maiores valores da densidade glandular, sugerindo que a morfologia das glândulas está associada com as concentrações de P4 circulante. Os autores ainda relatam que alterações entre a espessura do endométrio e as glândulas uterinas refletem interações entre hormônios esteróides gonadais, fatores de crescimento e componentes da matriz extracelular nas células epiteliais e do estroma. Apesar dos animais superovulados apresentarem aumento tanto no número total, quanto na 
densidade de glândulas, nos animais do grupo estimulado não foi encontrado aumento, o que nos faz inferir que este aumento esteja relacionado à diferença entre os valores de P4 plasmática nos grupos. Este valor de P4 nos animais do grupo superovulado é $85,12 \mathrm{~nm} / \mathrm{ml}$, enquanto que nos animais do grupo estimulado é $5,94 \mathrm{~nm} / \mathrm{ml}$, ou seja, aproximadamente 14 vezes menor.

Para testarmos se a P4 influenciaria um aumento no número total e na densidade das glândulas no grupo estimulado, uma alternativa poderia ser a coleta do material em outra fase do ciclo estral, como, por exemplo, na fase folicular. Esta sugestão poderia nos apresentar diferentes resultados, uma vez que vários autores compararam e encontraram resultados diferentes entre as fases folicular e luteínica, tanto no número de glândulas quanto na expressão de fatores de crescimento (WANG et al., 2007; SILVA et al., 2011).

Assim, a importância da P4 no preparo do ambiente uterino e também para a receptividade de implantação do embrião faz-se evidente e estratégias para aumentar a P4 no início da fase luteínica, podem garantir melhores resultados nas taxas de prenhez (BARUSELLI et al., 2000; LONERGAN, 2011). A P4 é ponto chave na criação de um ambiente uterino ideal, via composição do histotrófo, em que o embrião pode se desenvolver. Interações entre estes hormônios esteróides e fatores de crescimento, (WELTER et al., 2004) que desempenham função na proliferação e diferenciação celular, e desenvolvimento vascular (REYNOLDS, REDMER, 1992; ZENG; JENNER; MARSDEN, 1996; JOHNSON; REDMER; REYNOLDS, 1997), como o sistema VEGF-A, foco do estudo, podem também influenciar $O$ desenvolvimento glandular uterino.

De acordo com Welter et al (2004), a P4 aumenta a expressão de fatores de crescimento vascular, inclusive o VEGF (YOUN et al., 2004). Entretanto, a expressão do mRNA do sistema VEGF-A não variou entre os diferentes grupos, o que nos faz compreender que os efeitos do tratamento de estimulação e superovulação com eCG não alteram a expressão gênica deste fator de crescimento no útero a médio prazo. Mesmo que o local de coleta de amostra uterina pudesse influenciar a expressão gênica deste sistema observado, dados de Bauersachs et al (2005) nos levam a acreditar que não exista este tipo de influência em bovinos.

A proliferação e diferenciação do epitélio endometrial e das células do estroma são controladas por E2 e P4 (XIAO; GOFF, 1998). Estes autores afirmam 
que a expressão do mRNA do VEGF é aumentada pela estimulação do E2. Em nosso estudo também dosamos o E2 (Fátima, dados não publicados) dos animais no dia da coleta dos ovários e útero e verificamos que não houve diferença entre os três grupos, o que nos leva a acreditar que neste momento não possa ser mais verificada a provável influência do E2.

Um estudo recente (CHENNAZHI; NAYAK, 2009) apontou que a expressão do VEGF é estimulada por P4 na camada mais superficial de glândulas endometriais enquanto é suprimida no estroma uterino. No entanto, o mRNA do VEGF analisado no endométrio como um todo não demonstrou variação entre os grupos, como também não variou entre os cornos ipsolateral e contralateral ao CL nos casos dos grupos controle e estimulado. Tampouco observaram-se alterações em nível protéico quando analisamos os resultados de imunoistoquímica. Licht et al (2003) descrevem que ocorre variação de expressão do VEGF-A e seus receptores durante a fase proliferativa do ciclo estral, com um aumento adicional na expressão no momento da implantação. Baseados nestes fatos, sugerimos que um possível aumento do VEGF-A adicionalmente ao aumento da densidade glandular deve ter ocorrido como resposta ao tratamento com eCG em fase anterior à estudada. $A$ dose de 2000 UI de eCG administrada no dia -5 (ou dia 4 do protocolo) promove aumento da densidade de glândulas que ainda pode ser observado no dia 6 pós ovulação ou dia 11 após a administração do eCG, pois provavelmente deve aumentar a expressão do VEGF e seus receptores no útero anteriormente.

No entanto, esperaríamos encontrar diferenças na expressão do sistema VEGF-A mesmo nesta fase, pois dados do nosso grupo (PINTO, 2009) demonstraram que ocorre diminuição da densidade vascular no endométrio dos animais estimulados em relação aos grupos controle e superovulados, e no miométrio dos animais superovulados em relação aos outros dois grupos. É provável que o útero de um animal que não tenha sido inseminado (como foi o caso em nosso estudo) não necessite de maior vascularização nesta fase do ciclo. Inclusive foi relatado um desvio de sangue do útero para o ovário (BOLLWEIN; MAYER; STOLLA, 2003), em função de proporcionar um maior aporte de sangue para os múltiplos folículos ou corpos lúteos dos animais superovulados. Ao contrário, animais inseminados apresentam maior vascularização direcionada ao 
útero (BOLLWEIN; MAYER; STOLLA, 2003), o que atribui ao embrião um papel importante no processo de estabelecimento da gestação.

As interações que ocorrem entre o útero e o corpo lúteo são muito importantes para o estabelecimento de um ambiente uterino adequado para receber o embrião. Este, por sua vez, interage com ambos para garantir sua permanência e posterior nutrição. Este processo e muitos dos fatores nele envolvidos podem ser modulados pela administração de gonadotrofinas exógenas, como no presente estudo, visando otimizar o processo reprodutivo. Apesar de alguns autores (CLEMENTE et al., 2009) não conferirem ao embrião papel fundamental na regulação do ambiente uterino, nossos dados sugerem que o tratamento com eCG em doses estimulantes (400 UI) ou superestimulantes (2000 UI) por si só não acarreta diferenças na expressão gênica do sistema VEGF no endométrio, mas os dados referentes a densidade das glândulas e a correlação destes com a progesterona sérica nos animais do grupo superovulado, indicam uma resposta para melhorar o ambiente uterino visando futuras prenhezes. 


\section{CONCLUSÕES}

A partir dos resultados obtidos no presente trabalho pode-se concluir que:

- O tratamento com eCG não influencia a expressão gênica do sistema VEGF-A no útero após 11 dias de administração.

- A presença do CL não interfere na expressão gênica do sistema VEGF-A em qualquer corno uterino, seja ele ipso ou contralateral.

- O eCG, em doses superovulatórias, é capaz de induzir aumento da densidade e do número total de glândulas no endométrio. 


\section{REFERÊNCIAS}

ADAMS, G.P. Control of ovarian follicular wave dynamics in cattle: implications for synchronization and superstimulation. Theriogenology, v. 41, p. 19-24, 1994.

ARTAC, R.A.; MCFEE, R. M.; SMITH, R. A.; BALTES-BREITWISCH, M. M.; CLOPTON, D. T.; CUPP, A. S. Neutralization of vascular endothelial growth factor antiangiogenic isoforms is more effective than treatment with proangiogenic isoforms in stimulating vascular development and follicle progression in the perinatal rat ovary. Biology of Reproduction. v. 81(5) p. 978-88. 2009.

ASGERALLY, T.; FAZLEABAS; STRAKOVA, Z. Endometrial function: cell specific changes in the uterine environment. Molecular and cellular endocrinology. v. 186 p. 143-7. 2002.

ASSELIN, E.; FORTIER, M. A. Detection and regulation of the messenger for a putative bovine endometrial 9-keto-prostaglandin $\mathrm{E}(2)$ reductase: effect of oxytocin and interferon-tau. Biol Reprod, v. 62, n. 1, p. 125-131, 2000.

BARTOL, F. F.; WILEY, A. A.; COLEMAN, D. A.; WOLFE, D. F.; RIDDELL, M. G. J. Ovine uterine morphogenesis: effects of age and progestin administration and withdrawal on neonatal endometrial development and DNA synthesis. Animal Scince. v. 66(11) p.3000-9. 1988.

BARTOL, F. F.; WILEY, A. A.; FLOYD, J. G.; OTT, T. L,; BAZER, F. W.; GRAY, C. A.; SPENCER, T. E. Journal Reproduction and Fertilty Suppl. v. 54 p. 287-302.1999.

BARUSELLI, P. S.; MADUREIRA, E. H.; VISINTIN, J. A.; PORTO-FILHO, R.; CARVALHO, N. A. T.; CAMPANILE, G.; ZICARELLI, Z. Failure of oocyte entry into oviduct in superovulated buffalo. Theriogenology, v. 53, p. 491, 2000.

BARUSELLI, P. S.; MARQUES, M. O.; REIS, E. L.; MELLO, J. E.; CAMPOS FILHO, E.P. Taxa de concepção de diferentes protocolos de inseminação artificial em tempo fixo em vacas Bos taurus taurus $x$ Bos taurus indicus durante o período pós-parto. In: Simpósio Internacional de Reprodução Animal, 5., Proceedings, v.1, p.380, 2003.

BARUSELLI, P. S.; MADUREIRA, E. H.; MARQUES, M. O.; RODRIGUES, C. A.; NASSER, L. F. T.; SILVA, R. C. P.; REIS, E. L.; SÁ FILHO, M. F. Efeito do tratamento com eCG na taxa de concepção de vacas Nelore com diferentes escores de condição corporal inseminadas em tempo fixo (Análise retrospectiva). In: XVIII Reunião Anual da Sociedade Brasileira de Transferência de Embriões, 2004, Barra Bonita. Acta Scientiae Veterinariae, v. 32, p. 228, 2004a. 
BARUSELLI, P. S.; REIS, E. L.; MARQUES, M. O.; NASSER, L. F.; BÓ, G. A. The use of hormonal treatments to improve reproductive performance of anestrous beef cattle in tropical climates. Anim Reprod Sci, v. 82-83, n., p. 479-486, 2004b.

BARUSELLI, P. S.; SÁ FILHO, M. F.; MARTINS, C. M.; NASSER, L. F. T.; NOGUEIRA, M. F. G.; BARROS, C. M.; BO, G.A. Superovulation and embryo transfer in Bos indicus cattle. Theriogenology, v.65, p. 77-88, 2006.

BARUSELLI, P. S.; MARTINS, C. M.; SALES, J. N. S.; FERREIRA, R. M. Novos avanços na superovulação de bovinos. Acta Scientiae Veterinariae. v. 36 SUP, p. 433-448, 2008.

BARUSELLI, P. S.; FERREIRA, R. M.; SALES, J. N.; GIMENES, L. U.; SÁ FILHO, M. F.; MARTINS, C. M.; RODRIGUES, C. A.; BÓ, G. A. Timed embryo transfer programs for management of donor and recipient cattle. Theriogenology, v. 76, n. 9, p. 1583-1593, 2011.

BATES, D. O.; HARPER, S. J. Regulation of vascular permeability by vascular endothelial growth factors. Vascul Pharmacol, v. 39, n. 4-5, p. 225-237, 2002.

BAUERSACHS, S.; ULBRICH, S. E.; GROSS, K.; SCHMIDT, S. E.; MEYER, H. H.; EINSPANIER, R.; WENIGERKIND, H.; VERMEHREN, M.; BLUM, H.; SINOWATZ, F.; WOLF, E. Gene expression profiling of bovine endometrium during the oestrous cycle: detection of molecular pathways involved in functional changes. J Mol Endocrinol, v. 34, n. 3, p. 889-908, 2005.

BAZER, F. W. Uterine protein secretions: Relationship to development of the conceptus. J Anim Sci, v. 41, n. 5, p. 1376-1382, 1975.

BAZER, F. W.; SPENCER, T. E.; JOHNSON, G. A.; BURGHARDT, R. C.; WU, G. Comparative aspects of implantation. Reproduction, v. 138, n. 2, p. 195-209, 2009.

BINELLI, M. Estratégias anti-luteolíticas para a melhora da sobrevivênvia embrionária em bovinos. In: MADUREIRA E. H.; BARUSELLI, P. S. Controle farmacológico do ciclo estral em ruminantes, p. 99-114, São Paulo: FUNVET, 2001.

BÓ, G. A.; BARUSELLI, P. S.; MORENO, D.; CUTAIA, L.; CACCIA, M.; TRÍBULO, R.; TRÍBULO, H.; MAPLETOFT, R. J. The control of follicular wave development for self-appointed embryo transfer programs in cattle. Theriogenology, v. 57, n. 1, p. 5372, 2002.

BÓ, G. A.; BARUSELLI, P. S.; MARTÍNEZ, M. F. Pattern and manipulation of follicular development in Bos indicus cattle. Anim Reprod Sci, v. 78, n. 3-4, p. 307326, 2003.

BOONYARATANAKORNKIT, V.; MCGOWAN, E.; SHERMAN, L.; MANCINI, M. A.; CHESKIS, B. J.; EDWARDS, D. P. The role of extranuclear signaling actions of progesterone receptor in mediating progesterone regulation of gene expression and the cell cycle. Molecular Endocrinology. v. 21(2) p. 359-75. 2007. 
BOLLWEIN, H.; MAYER, R.; STOLLA, R. Transrectal Doppler sonography of uterine blood flow during early pregnancy in mares. Theriogenology, v. 60, p. 597-605, 2003

BRATTA, F. G.; CECI, O.; LOIZZI, P. Combined intra-uterine and cervical pregnancy treated successfully with methotrexate. Int J Gynaecol Obstet, v. 53, n. 2, p. 173174, 1996.

CAMPOS, D. B. Imunolocalização do VEGF, bFGF e seus receptores na placenta bovina e influência destes fatores sobre a produção de progesterona pelas células placentárias em cultura. 2005; 193 f. Tese (Doutorado em Ciências) - Faculdade de Medicina Veterinária e Zootecnia, Universidade de São Paulo, 2005.

CARSON-JURICA, M. A.; SCHRADER, W. T.; O'MALLEY, B. W. Steroid receptor family: structure and functions. Endocr Rev, v. 11, n. 2, p. 201-220, 1990.

CAVALIERI, J.; RUBIO, I.; KINDER, J.; ENTWISTLE, K.; FITZPATRICK, L. Synchronization of estrus and ovulation and associated endocrine changes in Bos indicus cows. Theriogenology, v. 47, n. 4, p. 801-814, 1997.

CHEN, J. I.; HANNAN, N. J.; MAK, Y.; NICHOLLS, P. K.; ZHANG, J.; RAINCZUK, A.; STANTON, P. G.; ROBERTSON, D. M.; SALAMONSEN, L. A.; STEPHENS, A. $\mathrm{N}$. Proteomic characterization of midproliferative and midsecretory human endometrium. J Proteome Res, v. 8, n. 4, p. 2032-2044, 2009.

CHENNAZHI, K. P.; NAYAK, N. R. Regulation of angiogenesis in the primate endometrium: vascular endothelial growth factor. Semin Reprod Med, v. 27, n. 1, p. 80-89, 2009.

CLEMENTE, M.; DE LA FUENTE, J.; FAIR, T.; AL NAIB, A.; GUTIERREZ-ADAN, A.; ROCHE, J. F.; RIZOS, D.; LONERGAN, P. Progesterone and conceptus elongation in cattle: a direct effect on the embryo or an indirect effect via the endometrium? Reproduction, v. 138, n. 3, p. 507-517, 2009.

DANTZER, V.; WINTHER, H. Histological and immunohistochemical events during placentation in pigs. Reprod Suppl, v. 58, n., p. 209-222, 2001.

DHALIWAL, G. S.; MURRAY, R. D.; REES, E. M.; HOWARD, C. V.; BEECH, D. J. Quantitative unbiased estimates of endometrial gland surface area and volume in cycling cows and heifers. Res Vet Sci, v. 73, n. 3, p. 259-265, 2002.

DI DIO, L. J. A. Tratado de Anatomia sistêmica aplicada. 2ª . Edição. Atheneu, São Paulo, 2002.

DINIZ, E. G.; JACOMINI, J. O.; NASCIMENTO, M. R. B. M.; MENDES JR., J. O. B.; ESPER, C. R. Eficiência de dois diferentes produtos hormonais na superovulação de vacas da raça Nelore. Revista Brasileira de Reprodução Animal, v. 23, n.3, p. 319-20, 1999.

DISKIN, M. G.; SREENAN, J. M. Fertilization and embryonic mortality rates in beef heifers after artificial insemination. J Reprod Fertil, v. 59, n. 2, p. 463-468, 1980. 
DISKIN, M. G.; MURPHY, J. J.; SREENAN, J. M. Embryo survival in dairy cows managed under pastoral conditions. Anim Reprod Sci, v. 96, n. 3-4, p. 297-311, 2006.

DISKIN, M. G.; MORRIS, D. G. Embryonic and early foetal losses in cattle and other ruminants. Reprod Domest Anim, v. 43 Suppl 2, n., p. 260-267, 2008.

DYCE, K. M.; SACK, W. O.; WENSING, C. J. G. Tratado de Anatomia Veterinária. 4ㅁ. Edição. Elsevier, Rio de Janeiro, 2010.

FAO. Food and agriculture organization of the united nations. Statistics. Faostat. Consumption. 2007. Disponível em: http://faostat.fao.org/site/342/default.aspx. acesso em:10 out. 2010.

FERRARA, N.; HOUCK, K.; JAKEMAN, L.; LEUNG, D. W. Molecular and biological properties of the vascular endothelial growth factor family of proteins. Endocr Rev, v. 13, n. 1, p. 18-32, 1992.

FERRARA, N.; CARVER-MOORE, K.; CHEN, H.; DOWD, M.; LU, L.; O'SHEA, K. S.; POWELL-BRAXTON, L.; HILLAN, K. J.; MOORE, M. W. Heterozygous embryonic lethality induced by targeted inactivation of the VEGF gene. Nature, v. 380, n. 6573, p. 439-442, 1996.

FERRARA, N.; CHEN, H.; DAVIS-SMYTH, T.; GERBER, H. P.; NGUYEN, T. N.; PEERS, D.; CHISHOLM, V.; HILLAN, K. J.; SCHWALL, R. H. Vascular endothelial growth factor is essential for corpus luteum angiogenesis. Nat Med, v. 4, n. 3, p. 336340, 1998.

FERRARA, N.; FRANTZ, G.; LECOUTER, J.; DILLARD-TELM, L.; PHAM, T.; DRAKSHARAPU, A.; GIORDANO, T.; PEALE, F. Differential expression of the angiogenic factor genes vascular endothelial growth factor (VEGF) and endocrine gland-derived VEGF in normal and polycystic human ovaries. Am J Pathol, v. 162, n. 6, p. 1881-1893, 2003a.

FERRARA, N.; GERBER, H. P.; LECOUTER, J. The biology of VEGF and its receptors. Nat Med, v. 9, n. 6, p. 669-676, 2003b.

FERRARA, N. Vascular endothelial growth factor: basic science and clinical progress. Endocr Rev, v. 25, n. 4, p. 581-611, 2004.

FIELDS, M. J.; FIELDS, P. A. Morphological characteristics of the bovine corpus luteum during the estrous cycle and pregnancy. Theriogenology, v. 45, n. 7, p. 12951325, 1996.

FILICORI, M.; FAZLEABAS, A. T.; HUHTANIEMI, I.; LICHT, P.; RAO, C. V.; TESARIK, J.; ZYGMUNT, M. Novel concepts of human chorionic gonadotropin: reproductive system interactions and potential in the management of infertility. Fertil Steril, v. 84, n. 2, p. 275-284, 2005.

FORD, S. P.; CHENAULT, J. R.; ECHTERNKAMP, S. E. Uterine blood flow of cows during the oestrous cycle and early pregnancy: effect of the conceptus on the uterine blood supply. J Reprod Fertil, v. 56, n. 1, p. 53-62, 1979. 
FORDE, N.; SPENCER, T. E.; BAZER, F. W.; SONG, G.; ROCHE, J. F.; LONERGAN, P. Effect of pregnancy and progesterone concentration on expression of genes encoding for transporters or secreted proteins in the bovine endometrium. Physiol Genomics, v. 41, n. 1, p. 53-62, 2010.

FUENTES, S.; DE LA FUENTES, J. Different synchronization treatments for direct embryo transfer to recipient heifers. Proceedings of the 13 th Annual Meeting of the European Embryo Transfer Association. AETE. p. 148, 1997.

FUCK, E. J.; MORAES, G. V.; MARTINS, E. N.; FALCÃO, A. J. S.; RODRIGUES, C. M.; CARDOZO, R. M.; BARROS, C. M. Uso da gonadotrofina coriônica eqüina em receptoras de embriões para avaliar o incremento da progesterona endógena no dia da inovulação e sua correlação com a taxa de prenhez. Acta Scientiarum, Maringá, v. 24, n. 4, p. 1119-1126, 2002.

GATELY, S. The contributions of cyclooxygenase-2 to tumor angiogenesis. Cancer Metastasis Rev, v. 19, n. 1-2, p. 19-27, 2000.

GEVA, E.; JAFFE, R. B. Role of vascular endothelial growth factor in ovarian physiology and pathology. Fertil Steril, v. 74, n. 3, p. 429-438, 2000.

GIUDICE, G. Molecular mechanisms in developmental biology. Cell Biol Int, v. 20, n. 1, p. 29-32, 1996.

GONZALEZ, H. E.; CROWELL, W. A.; CAUDLE, A. B.; THOMPSON, F. N. Morphometric studies of the bovine uterus: microscopic lesions and retrospective reproductive history. Am J Vet Res, v. 46, n. 12, p. 2588-2595, 1985.

GRAY, C. A.; BARTOL, F. F.; TARLETON, B. J.; WILEY, A. A.; JOHNSON, G. A.; BAZER, F. W.; SPENCER, T. E. Developmental biology of uterine glands. Biol Reprod, v. 65, n. 5, p. 1311-1323, 2001.

GUNDERSEN, H. J.; BENDTSEN, T. F.; KORBO, L.; MARCUSSEN, N.; MØLLER, A.; NIELSEN, K.; NYENGAARD, J. R.; PAKKENBERG, B.; SØRENSEN, F. B.; VESTERBY, A. Some new, simple and efficient stereological methods and their use in pathological research and diagnosis. APMIS, v. 96, n. 5, p. 379-394, 1988.

HAFEZ, E. S. E. Fisiologia da reprodução. In: HAFEZ, E. S. E. (Ed). Reprodução animal. $7^{\text {th }}$ ed. São Paulo: Ed. Manole, 2004.

HARPER, S. J.; BATES, D. O. VEGF-A splicing: the key to anti-angiogenic therapeutics? Nat Rev Cancer, v. 8, n. 11, p. 880-887, 2008.

HASLER, J. F. Factors affecting frozen and fresh embryo transfer pregnancy rates in cattle. Theriogenology, v. 56, n. 9, p. 1401-1415, 2001.

HERR, D.; KECK, C.; TEMPFER, C.; PIETROWSKI, D. Chorionic gonadotropin regulates the transcript level of $\mathrm{VHL}$, p53, and $\mathrm{HIF}$-2alpha in human granulosa lutein cells. Mol Reprod Dev, v. 69, n. 4, p. 397-401, 2004. 
HERVÉ, M. A.; MEDURI, G.; PETIT, F. G.; DOMET, T. S.; LAZENNEC, G.; MOURAH, S.; PERROT-APPLANAT, M. Regulation of the vascular endothelial growth factor (VEGF) receptor Flk-1/KDR by estradiol through VEGF in uterus. Jounal of Endocrinology, v. 188, n. 1, p. 91-99, 2006.

HERYANTO, B.; LIPSON, K. E.; ROGERS, P. A. Effect of angiogenesis inhibitors on oestrogen-mediated endometrial endothelial cell proliferation in the ovariectomized mouse. Reproduction, v. 125, n. 3, p. 337-346, 2003.

HONNENS, A.; NIEMANN, H.; PAUL, V.; MEYER, H. H.; BOLLWEIN, H. Doppler sonography of the uterine arteries during a superovulatory regime in cattle. Uterine blood flow in superovulated cattle. Theriogenology, v. 70, n. 5, p. 859-867, 2008.

HUMBLOT, P. Use of pregnancy specific proteins and progesterone assays to monitor pregnancy and determine the timing, frequencies and sources of embryonic mortality in ruminants. Theriogenology, v. 56, n. 9, p. 1417-1433, 2001.

HYDER, S. M.; STANCEL, G. M.; CHIAPPETTA, C.; MURTHY, L.; BOETTGERTONG, H. L.; MAKELA, S. Uterine expression of vascular endothelial growth factor is increased by estradiol and tamoxifen. Cancer Res, v. 56, n. 17, p. 3954-3960, 1996.

HYDER, S. M. The role of steroid hormones on the regulation of vascular endothelial growth factor. Am J Pathol, v. 161, n. 1, p. 345-346, 2002.

ING, N.H.; TORNESI, M. B. Estradiol up-regulates estrogen receptor and progesterone receptor gene expression in specific ovine uterine cells. Biology of Reproduction. v. 56(5) p.1205-15. 1997.

JOHANNISSON, E.; LANDGREN, B. M.; ROHR, H. P.; DICZFALUSY, E . Endometrial morphology and peripheral hormone levels in women with regular menstrual cycles. Fertility and Sterility. v. 48, p. 401-408. 1987.

JOHANNISSON, E. Morphological and histochemical factors related to implantation. Baillieres Clin Obstet Gynaecol, v. 5, n. 1, p. 191-209, 1991.

JOHNSON, M. L.; REDMER, D. A.; REYNOLDS, L. P. Effects of ovarian steroids on uterine growth, morphology, and cell proliferation in ovariectomized, steroid-treated ewes. Biol Reprod, v. 57, n. 3, p. 588-596, 1997.

JUNQUEIRA, L. C.; CARNEIRO, J. Aparelho reprodutor feminino. In: JUNQUEIRA, L. C.; CARNEIRO, J. (Ed). Histologia básica. 10ª ed. São Paulo: Ed. Guanabara Koogan, 2004

KUMAR, S.; BRUDNEY, A.; CHEON, Y.P.; FAZLEABAS, A. T.; BAGCHI, I. C. Progesterone induces calcitonin expression in the baboon endometrium within the window of uterine receptivity. Biology of Reproduction. v. 68(4) p. 1318-23. 2003. 
LANGE, T.; GUTTMANN-RAVIV, N.; BARUCH, L.; MACHLUF, M.; NEUFELD, G. VEGF162, a new heparin-binding vascular endothelial growth factor splice form that is expressed in transformed human cells. J Biol Chem, v. 278, n. 19, p. 1716417169, 2003.

LECCE, G.; MEDURI, G.; ANCELIN, M.; BERGERON, C.; PERROT-APPLANAT, M. Presence of estrogen receptor beta in the human endometrium through the cycle: expression in glandular, stromal, and vascular cells. Journal Clinical Endocrinology Metabolism. v. 86(3) p.1379-86. 2001.

LEE, K. Y.; DEMAYO, F. J. Animal models of implantation. Reproduction, v. 128, n. 6, p. 679-695, 2004.

LI, X.; O'MALLEY, B. W. Unfolding the action of progesterone receptors. J Biol Chem, v. 278, n. 41, p. 39261-39264, 2003.

LICHT, P.; RUSSU, V.; LEHMEYER, S.; WISSENTHEIT, T.; SIEBZEHNRÜBL, E.; WILDT, L. Cycle dependency of intrauterine vascular endothelial growth factor levels is correlated with decidualization and corpus luteum function. Fertil Steril. v. 80, p. 1228-33. 2003.

LONERGAN, P. Influence of progesterone on oocyte quality and embryo development in cows. Theriogenology, v. 76, n. 9, p. 1594-1601, 2011.

MARINOV, U.; LOVELL, J. E. Cytology of the bovine uterine epithelium during the estrous cycle. Am J Vet Res, v. 29, n. 1, p. 13-30, 1968.

MARQUES, M.O.; SÁ FILHO, M.F.; GIMENES, L.U.; FIGUEIREDO, T B; SORIA, G F; BARUSELLI, P.S. Efeito do tratamento com PGF2a na inserção e/ou tratamento com eCG na remoção do dispositivo intravaginal de progesterona na taxa de concepção à inseminação artificial em tempo fixo em novilhas nelore. In: Acta Scientiae Veterinariae, 2005, Angra dos Reis/RJ. Acta Scientiae Veterinariae. v. 1, p. 287-287, 2005.

MASLAR, I. A.; POWERS-CRADDOCK, P.; ANSBACHER, R. Decidual prolactin production by organ cultures of human endometrium: effects of continuous and intermittent progesterone treatment. Biol Reprod, v. 34, n. 4, p. 741-750, 1986.

MATSUMOTO, L. C.; BOGIC, L.; BRACE, R. A.; CHEUNG, C. Y. Prolonged hypoxia upregulates vascular endothelial growth factor messenger RNA expression in ovine fetal membranes and placenta. Am J Obstet Gynecol, v. 186, n. 2, p. 303-310, 2002.

MONTIEL, F.; AHUJA, C. Body condition and suckling as factors influencing the duration of postpartum anestrus in cattle: a review. Anim Reprod Sci, v. 85, n. 1-2, p. 1-26, 2005.

MOOR, R. M.; KRUIP, T. A. M.; GREEN, D. Intra ovarian control of foliculogenesis: limits to superovulation; Theriogenology, v. 21, n. 1, p. 103-116, 1984. 
MULAC-JERICEVIC, B.; MULLINAX, R. A.; DEMAYO, F. J.; LYDON, J. P.; CONNEELY, O. M. Subgroup of reproductive functions of progesterone mediated by progesterone receptor-B isoform. Science, v. 289, n. 5485, p. 1751-1754, 2000.

MULAC-JERICEVIC, B.; LYDON, J. P.; DEMAYO, F. J.; CONNEELY, O. M. Defective mammary gland morphogenesis in mice lacking the progesterone receptor B isoform. Proc Natl Acad Sci U S A, v. 100, n. 17, p. 9744-9749, 2003.

MURPHY, B. D.; MARTINUK, S. D. Equine chorionic gonadotropin. Endocr Rev, v. 12, n. 1, p. 27-44, 1991.

NAGY, J. A.; VASILE, E.; FENG, D.; SUNDBERG, C.; BROWN, L. F.; MANSEAU, E. J.; DVORAK, A. M.; DVORAK, H. F. VEGF-A induces angiogenesis, arteriogenesis, lymphangiogenesis, and vascular malformations. Cold Spring Harb Symp Quant Biol, v. 67, n., p. 227-237, 2002.

N. A. V. Nomina Anatomica Veterinaria. 5a.ed. 2005

NG, Y. S.; KRILLEKE, D.; SHIMA, D. T. VEGF function in vascular pathogenesis. Exp Cell Res, v. 312, n. 5, p. 527-537, 2006.

NOWAK, D. G.; WOOLARD, J.; AMIN, E. M.; KONOPATSKAYA, O.; SALEEM, M. A.; CHURCHILL, A. J.; LADOMERY, M. R.; HARPER, S. J.; BATES, D. O. Expression of pro- and anti-angiogenic isoforms of VEGF is differentially regulated by splicing and growth factors. J Cell Sci, v. 121, n. Pt 20, p. 3487-3495, 2008.

OGLE, T. F. Progesterone-action in the decidual mesometrium of pregnancy. Steroids. v. 67(1) p.1-14. 2002.

OKUMU, L. A.; FORDE, N.; FAHEY, A. G.; FITZPATRICK, E.; ROCHE, J. F.; CROWE, M. A.; LONERGAN, P. The effect of elevated progesterone and pregnancy status on mRNA expression and localisation of progesterone and oestrogen receptors in the bovine uterus. Reproduction, v. 140, n. 1, p. 143-153, 2010.

PAPA, P. C.; MOURA, C. E.; ARTONI, L. P.; FÁTIMA, L. A.; CAMPOS, D. B.; MARQUES, J. E.; BARUSELLI, P. S.; BINELLI, M.; PFARRER, C.; LEISER, R. VEGF system expression in different stages of estrous cycle in the corpus luteum of non-treated and superovulated water buffalo. Domest Anim Endocrinol, v. 33, n. 4, p. 379-389, 2007.

PARK, J. E.; CHEN, H. H.; WINER, J.; HOUCK, K. A.; FERRARA, N. Placenta growth factor. Potentiation of vascular endothelial growth factor bioactivity, in vitro and in vivo, and high affinity binding to Flt-1 but not to Flk-1/KDR. J Biol Chem, v. 269, n. 41, p. 25646-25654, 1994.

PEGORER, M. F.; ERENO, R. L.; SATRAPA, R. A.; PINHEIRO, V. G.; TRINCA, L. A.; BARROS, C. M. Neither plasma progesterone concentrations nor exogenous eCG affects rates of ovulation or pregnancy in fixed-time artificial insemination 
(FTAl) protocols for puberal Nellore heifers. Theriogenology, v. 75, n. 1, p. 17-23, 2011.

PERROT-APPLANAT, M.; DENG, M.; FERNANDEZ, H.; LELAIDIER, C.; MEDURI, G.; BOUCHARD, P. Immunohistochemical localization of estradiol and progesterone receptors in human uterus throughout pregnancy: expression in endometrial blood vessels. J Clin Endocrinol Metab, v. 78, n. 1, p. 216-224, 1994.

PFAFFL, M. W. A new mathematical model for relative quantification in real-time RTPCR. Nucleic Acids Res, v. 29, n. 9, p. e45, 2001.

PFARRER, C. D.; RUZIWA, S. D.; WINTHER, H.; CALLESEN, H.; LEISER, R.; SCHAMS, D.; DANTZER, V. Localization of vascular endothelial growth factor (VEGF) and its receptors VEGFR-1 and VEGFR-2 in bovine placentomes from implantation until term. Placenta, v. 27, n. 8, p. 889-898, 2006.

PINTO, J. M. eCG e densidade vascular em úteros bovino. 2009; 97 f. Dissertação (Mestrado em Ciências) - Faculdade de Medicina Veterinária e Zootecnia, Universidade de São Paulo, 2009.

POLTORAK, Z.; COHEN, T.; SIVAN, R.; KANDELIS, Y.; SPIRA, G.; VLODAVSKY, I.; KESHET, E.; NEUFELD, G. VEGF145, a secreted vascular endothelial growth factor isoform that binds to extracellular matrix. J Biol Chem, v. 272, n. 11, p. 71517158, 1997.

PRIEDKALNS, B. Female reproductive system. In: DELLMANN H. D.; BROWN, E. M. (Ed.). Textbook of Veterinary Histology. Philadelphia: Lea and Febiger, p. 319349, 1976.

PURSLEY, J. R.; MEE, M. O.; WILTBANK, M. C. Synchronization of ovulation in dairy cows using PGF2alpha and GnRH. Theriogenology, v. 44, n. 7, p. 915-923, 1995.

RAMAKERS, C.; RUIJTER, J. M.; DEPREZ, R. H.; MOORMAN, A. F. Assumptionfree analysis of quantitative real-time polymerase chain reaction (PCR) data.

Neurosci Lett, v. 339, n. 1, p. 62-66, 2003.

REICHENBACH, H. D.; OLIVEIRA, M. A. L.; LIMA, P. F.; SANTOS FILHO, A. S.; ANDRADE, J. C. O. Transferência e criopreservação de embriões bovinos. In: GONSALVES, P. B. D.; FIGUEIREDO, J. R.; FREITAS, V. J. F. Biotécnicas Aplicadas à Reprodução Animal, p.153-160, São Paulo: Varela, 2002.

REIS, E. L.; MARQUES, M. O.; CARVALHO, N. A. T., NASSER, C L. F.; COSTA NETO, W. P.; BARUSELLI, P. S. Aumento da taxa de concepção em receptoras de embrião bovino com maiores concentrações plasmáticas de progesterona no dia da inovulação. Acta Scientiae Veterinariae, 32: 88, 2004.

REYNOLDS, L. P.; REDMER, D. A. Growth and microvascular development of the uterus during early pregnancy in ewes. Biol Reprod, v. 47, n. 5, p. 698-708, 1992. 
RICHER, J. K.; LANGE, C. A.; WIERMAN, A. M.; BROOKS, K. M.; TUNG, L.; TAKIMOTO, G. S.; HORWITZ, K. B. Progesterone receptor variants found in breast cells repress transcription by wild-type receptors. Breast Cancer Res Treat, v. 48, n. 3, p. 231-241, 1998.

ROBERTS, G. P.; PARKER, J. M. Fractionation and comparison of proteins from bovine uterine fluid and bovine allantoic fluid. Biochim Biophys Acta, v. 446, n. 1, p. 69-76, 1976.

SÁ FILHO, M. F.; AYRES, H.; FERREIRA, R. M.; NICHI, M.; FOSADO, M.; CAMPOS FILHO, E. P.; BARUSELLI, P. S. Strategies to improve pregnancy per insemination using sex-sorted semen in dairy heifers detected in estrus. Theriogenology, v. 74, n. 9, p. 1636-1642, 2010.

SAĞSÖZ, H.; SARUHAN, B. G. The expression of vascular endothelial growth factor and its receptors (flt1/fms, flk1/KDR, flt4) and vascular endothelial growth inhibitor in the bovine uterus during the sexual cycle and their correlation with serum sex steroids. Theriogenology, v. 75, n. 9, p. 1720-1734, 2011.

SALES, J. N. S.; CREPALDI, G. A.; GIROTTO, R. W.; SOUZA, A. H.; BARUSELLI, $P$. S. Fixed-time Al protocols replacing eCG with a single dose of $\mathrm{FSH}$ were less effective in stimulating follicular growth, ovulation, and fertility in suckled-anestrus Nelore beef cows. Animal Reproduction Science. v.1-2 p.12-18. 2011.

SANTOS, F.; DEAN, W. Epigenetic reprogramming during early development in mammals. Reproduction, v. 127, n. 6, p. 643-651, 2004.

SHALABY, F.; ROSSANT, J.; YAMAGUCHI, T. P.; GERTSENSTEIN, M.; WU, X. F.; BREITMAN, M. L.; SCHUH, A. C. Failure of blood-island formation and vasculogenesis in Flk-1-deficient mice. Nature, v. 376, n. 6535, p. 62-66, 1995.

SHIMIZU, T.; JIANG, J. Y.; SASADA, H.; SATO, E. Changes of messenger RNA expression of angiogenic factors and related receptors during follicular development in gilts. Biology of Reproduction. v. 67, p. 1846-52.2002

SIQUEIRA, L. G. B.; TORRES, C. A. A.; SOUZA, E. D.; MONTEIRO JR, P. L. J.; ARASHIROE, K. N.; CAMARGO, L. S. A.; FERNANDES, C. A. C.; VIANA, J. H. M. Pregnancy rates and corpus luteum-related factors affecting pregnancy. Theriogenology. v. 72(7) p. 949-58, 2009.

SILVA, L. A.; KLEIN, C.; EALY, A. D.; SHARP, D. C. Conceptus-mediated endometrial vascular changes during early pregnancy in mares: an anatomic, histomorphometric, and vascular endothelial growth factor receptor system immunolocalization and gene expression study. Reproduction, v. 142, n. 4, p. 593603, 2011.

SOUSA, L. M. M. C. Efeitos do VEGF e do bFGF sobre a expressão da aromatase P450 em cultivo de células placentárias provenientes de bovinos clonados e não clonados. 2007; 197f. Dissertação (Mestrado em Ciências). Faculdade de Medicina Veterinária e Zootecnia, Universidade de São Paulo, 2007. 
SOUZA, A. F.; PEGORER, M. F.; SATRAPA, R. A.; ERENO, R. L.; TRINCA, L. A.; BARROS, C. M. Effects of temporary calf removal and eCG on pregnancy rates to timed-insemination in progesterone-treated postpartum Nellore cows.

Theriogenology. v. 71(3) p.519-24. 2009.

SMITH, S. K. Angiogenesis, vascular endothelial growth factor and the endometrium. Hum Reprod Update, v. 4, n. 5, p. 509-519, 1998.

SMITH, S. K. Regulation of angiogenesis in the endometrium. Trends Endocrinol Metab, v. 12, n. 4, p. 147-151, 2001.

SOUMANO, K.; PRICE, C. A. Ovarian follicular steroidogenic acute regulatory protein, low-density lipoprotein receptor, and cytochrome P450 side-chain cleavage messenger ribonucleic acids in cattle undergoing superovulation. Biol Reprod, v. 56, n. 2, p. 516-522, 1997.

SPENCER, T. E.; BAZER, F. W. Uterine and placental factors regulating conceptus growth in domestic animals. J Anim Sci, v. 82 E-Suppl, n., p. E4-13, 2004.

SPENCER, T. E.; GRAY, C. A. Sheep uterine gland knockout (UGKO) model. Methods Mol Med, v. 121, n., p. 85-94, 2006.

SREENAN, J. M. Non-surgical egg recovery and transfer in the cow. Vet Rec, v. 102, n. 3, p. 58-60, 1978.

STEWART, F.; ALLEN, W. R. Biological functions and receptor binding activities of equine chorionic gonadotrophins. J Reprod Fertil, v. 62, n. 2, p. 527-536, 1981.

TAMMELA, T.; ENHOLM, B.; ALITALO, K.; PAAVONEN, K. The biology of vascular endothelial growth factors. Cardiovasc Res, v. 65, n. 3, p. 550-563, 2005.

TEZUKA, N.; ALI, M.; CHWALISZ, K.; GARFIELD, R. E. Changes in transcripts encoding calcium channel subunits of rat myometrium during pregnancy. Am J Physiol, v. 269, n. 4 Pt 1, p. C1008-1017, 1995.

TSAI, M. J.; O'MALLEY, B. W. Molecular mechanisms of action of steroid/thyroid receptor superfamily members. Annu Rev Biochem, v. 63, n., p. 451-486, 1994.

UGUR, Y.; CAKAR, A. N.; BEKSAC, M. S.; DAGDEVIREN, A. Activation antigens during the proliferative and secretory phases of endometrium and early-pregnancy decidua. Gynecol Obstet Invest, v. 62, n. 2, p. 66-74, 2006.

WAHAB, M.; THOMPSON, J.; HAMID, B.; DEEN, S.; AL-AZZAWI, F. Endometrial histomorphometry of trimegestone-based sequential hormone replacement therapy: a weighted comparison with the endometrium of the natural cycle. Hum Reprod, v. 14, n. 10, p. 2609-2618, 1999.

WANG, C. K.; ROBINSON, R. S.; FLINT, A. P.; MANN, G. E. Quantitative analysis of changes in endometrial gland morphology during the bovine oestrous cycle and their association with progesterone levels. Reproduction, v. 134, n. 2, p. 365-371, 2007. 
WELTER, H.; BOLLWEIN, H.; WEBER, F.; ROHR, S.; EINSPANIER, R. Expression of endothelial and inducible nitric oxide synthases is modulated in the endometrium of cyclic and early pregnant mares. Reprod Fertil Dev, v. 16, n. 7, p. 689-698, 2004.

WILLIAMS, G. L.; GAZAL, O.S.; GUZMÁN VEGA, G. A.; STANKO, R. L. Mechanisms regulating suckling-mediated anovulation in the cow. Animal Reproduction Science, v.42, p.289-297, 1996.

WILLIAMS, G. L. Suckling as a regulator of postpartum rebreeding in cattle: a review. J Anim Sci, v. 68, n. 3, p. 831-852, 1990.

XIAO, C. W.; GOFF, A. K. Differential effects of oestradiol and progesterone on proliferation and morphology of cultured bovine uterine epithelial and stromal cells. J Reprod Fertil, v. 112, n. 2, p. 315-324, 1998.

YOUN, J.; CHO, M. L.; KIM, Y. J.; YUN, H. S.; PARK, S. H.; JIN, C. Z; PAIK, D. J.; $\mathrm{KIM}, \mathrm{H}$. Y. New cyclooxygenase-2 inhibitor DFU regulates vascular endothelial growth factor expression in rheumatoid synoviocytes. Immunol Lett. v. 31, p.219-24. 2004.

ZENG, B. Y.; JENNER, P.; MARSDEN, C. D. Altered motor function and graft survival produced by basic fibroblast growth factor in rats with 6-OHDA lesions and fetal ventral mesencephalic grafts are associated with glial proliferation. Exp Neurol, v. 139, n. 2, p. 214-226, 1996. 